\title{
Seasonal variation of aerosol water uptake and its impact on the direct radiative effect at $\mathrm{Ny}$-Ålesund, Svalbard
}

\author{
N. Rastak $^{1}$, S. Silvergren ${ }^{3,}$, P. Zieger ${ }^{1}$, U. Wideqvist ${ }^{1}$, J. Ström ${ }^{1}$, B. Svenningsson ${ }^{3}$, M. Maturilli ${ }^{4}$, M. Tesche ${ }^{1}$, A. M. \\ L. Ekman ${ }^{2}$, P. Tunved ${ }^{1}$, and I. Riipinen ${ }^{1}$ \\ ${ }^{1}$ Department of Applied Environmental Science (ITM) and Bert Bolin Centre for Climate Research, Stockholm University, \\ S 11418 Stockholm, Sweden \\ ${ }^{2}$ Department of Meteorology (MISU) and Bert Bolin Centre for Climate Research, Stockholm University, \\ S 10691 Stockholm, Sweden \\ ${ }^{3}$ Division of Nuclear Physics, Lund University, P.O. Box 118, SE-21100 Lund, Sweden \\ ${ }^{4}$ Alfred Wegener Institute, Helmholtz Centre for Polar and Marine Research, Telegrafenberg A43, 14473 Potsdam, Germany \\ *now at: Stockholm Environment and Health Administration, P.O. Box 8136, 10420 Stockholm, Sweden \\ Correspondence to: N. Rastak (narges.rastak@itm.su.se)
}

Received: 25 November 2013 - Published in Atmos. Chem. Phys. Discuss.: 17 March 2014

Revised: 14 May 2014 - Accepted: 6 June 2014 - Published: 21 July 2014

\begin{abstract}
In this study we investigated the impact of water uptake by aerosol particles in ambient atmosphere on their optical properties and their direct radiative effect (ADRE, $\mathrm{W} \mathrm{m}^{-2}$ ) in the Arctic at Ny-Ålesund, Svalbard, during 2008. To achieve this, we combined three models, a hygroscopic growth model, a Mie model and a radiative transfer model, with an extensive set of observational data. We found that the seasonal variation of dry aerosol scattering coefficients showed minimum values during the summer season and the beginning of fall (July-August-September), when small particles $(<100 \mathrm{~nm}$ in diameter $)$ dominate the aerosol number size distribution. The maximum scattering by dry particles was observed during the Arctic haze period (MarchApril-May) when the average size of the particles was larger. Considering the hygroscopic growth of aerosol particles in the ambient atmosphere had a significant impact on the aerosol scattering coefficients: the aerosol scattering coefficients were enhanced by on average a factor of $4.30 \pm 2.26$ (mean \pm standard deviation), with lower values during the haze period (March-April-May) as compared to summer and fall. Hygroscopic growth of aerosol particles was found to cause 1.6 to 3.7 times more negative ADRE at the surface, with the smallest effect during the haze period (March-AprilMay) and the highest during late summer and beginning of fall (July-August-September).
\end{abstract}

\section{Introduction}

Atmospheric aerosol particles influence Earth's energy budget directly by scattering and absorbing radiation (McCormick and Ludwig, 1967; Charlson and Pilat, 1969; Atwater, 1970; Mitchell Jr., 1971; Coakley et al., 1983) and indirectly by acting as cloud condensation nuclei and thereby modifying cloud properties (Twomey, 1977; Albrecht, 1989; Charlson et al., 1992; Hegg, 1994; Boucher and Lohmann, 1995). A better understanding of the radiative impacts of atmospheric aerosols is needed for quantifying the factors determining Earth's energy balance and driving changes in global climate (IPCC, 2013). In this study we focus on the aerosol direct radiative effect (ADRE), whose magnitude is determined by the chemical composition, size distribution, shape, and particle concentration profiles of the atmospheric aerosols, Earth's surface albedo and the solar zenith angle (Yu et al., 2006).

Water is an important chemical component in atmospheric aerosol particles and, thus, can affect ADRE (e.g., Myhre et al., 2004). For example, it has been estimated that increasing the relative humidity (RH) from $40 \%$ to $80-90 \%$ could double the direct negative radiative forcing caused by aerosols (Pilinis et al., 1995; Fierz-Schmidhauser et al., 2010a). The water content of a given atmospheric aerosol population is determined by the ambient $\mathrm{RH}$ together with the composition, particularly water solubility, and dry size distribution of the aerosol particles. In situ measurements of aerosol size 
distributions and optical properties, however, often take place at dry or nearly dry conditions. Therefore, to evaluate the impact of aerosol water content on ADRE, the measurements at dry conditions need to be corrected for the hygroscopic growth of the aerosol particles under humid ambient atmospheric conditions. The water uptake (hygroscopicity) of aerosol particles in equilibrium with the atmospheric water vapor can be modeled using the $\kappa$-Köhler theory (e.g., Petters and Kreidenweis, 2007), where the aerosol water uptake is represented with a single hygroscopicity parameter $\kappa$.

Numerous experimental and modeling studies have investigated the influence of $\mathrm{RH}$ on optical properties of aerosol particles, which is often described with the enhancement factor $f(\mathrm{RH})$, defined as the ratio of aerosol scattering coefficient at a given RH and the scattering coefficient at dry conditions (see e.g., Zieger et al., 2010). $f(\mathrm{RH})$ has been investigated in a number of studies at various locations (see Table 1), typically by comparing the signal of a nephelometer operated at a given $\mathrm{RH}$ to a corresponding instrument at dry conditions. The reported values vary from almost no enhancement $(f=1)$ to a considerable effect on the optical properties $(f>3)$, depending on the location.

Temperature variability and climate trends in the Arctic region tend to be more pronounced than the corresponding trends and variability for the Northern Hemisphere or the globe as a whole, resulting from the different feedbacks active in the Arctic environment. This characteristic feature of the climate system is referred to as the Arctic amplification and it is expected to become stronger in the upcoming decades (Serreze and Barry, 2011). The impacts of Arctic amplification can also extend outside the Arctic region (Lawrence et al., 2008). Arctic temperatures have increased at almost twice the global average rate over the past 100 years (IPCC, 2013), contributing to a continuous reduction of Arctic summer sea ice cover and surface albedo since 1979 (Serreze et al., 2007). The Arctic region thus appears to be more sensitive to greenhouse-gas-induced warming than the rest of the globe. Shindell and Faluvegi (2009) also showed that the Arctic climate is particularly sensitive to changes in the Northern Hemisphere aerosol forcing, induced both by altered particle and precursor emissions as well as atmospheric water content.

In this manuscript we investigate the seasonality of the enhancement of the direct aerosol forcing in the Arctic caused by aerosol hygroscopic growth, focusing on the year 2008 . We calculate seasonal enhancement factors $f(\mathrm{RH})$ by driving a coupled hygroscopic growth and aerosol light scattering model with measured atmospheric aerosol size distribution, composition, temperature, and RH data collected at the Mt Zeppelin station in Ny-Ålesund, Svalbard. We evaluate the model calculations using campaign data on the hygroscopic growth and aerosol optical properties (Silvergren et al., 2014; Zieger et al., 2010). Furthermore, we investigate the influence of the hygroscopic growth on the direct radiative forcing.

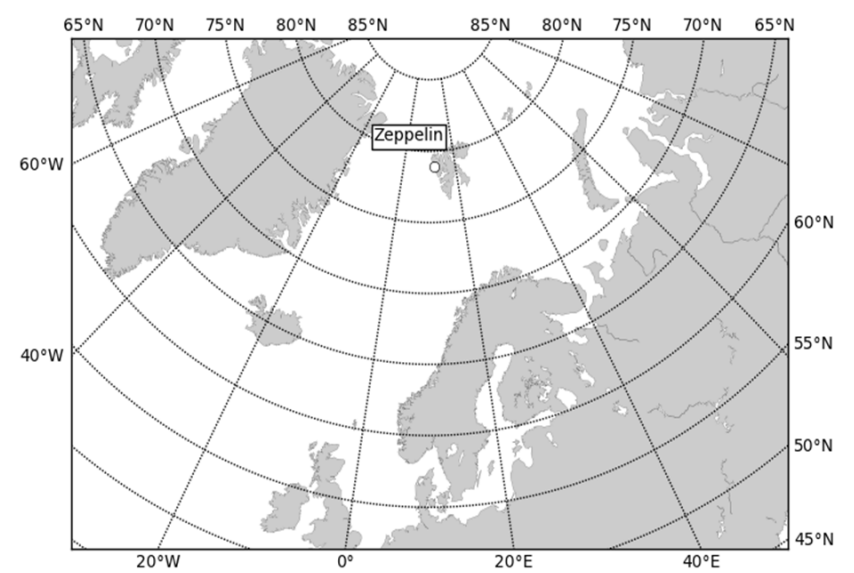

Figure 1. Mt Zeppelin station, Ny Ålesund, Svalbard at $78^{\circ} 54^{\prime} \mathrm{N}$, $11^{\circ} 53^{\prime} \mathrm{E}$ (474 $\mathrm{m}$ a.s.1.).

\section{Mt Zeppelin station, Ny-Ålesund, Svalbard}

All the measurements except for the soundings and surface albedo used in this study (see Sect. 4) were conducted at the Mt Zeppelin station. The observatory is located in the Arctic on Zeppelin Mountain, close to Ny-Ålesund, in the archipelago of Svalbard at $78^{\circ} 54^{\prime} \mathrm{N}, 11^{\circ} 53^{\prime} \mathrm{E}$ (Fig. 1). The station is located in an almost pristine Arctic environment, away from major pollution sources. Influence from local pollution sources, such as from the nearby community of NyAlesund, is also limited by the location of the observatory at 474 meters above sea level (m a.s.l.). The unique location of the observatory makes it an ideal platform for monitoring global atmospheric change and long-range pollution transport. The observatory belongs to the Norwegian Polar Research Institute (NP) and the Norwegian Institute for Air Research (NILU) is responsible for the scientific program performed at the station (Ström et al., 2003; Tunved et al., 2013). The soundings and surface albedo measurements were conducted at the village of Ny-Ålesund.

\section{Model setup}

To examine the effect of hygroscopic growth on aerosol optical properties and the aerosol's direct effect in the Arctic, three different models were utilized. First, we modeled the hygroscopic growth of aerosol particles in ambient atmosphere using the $\kappa$-Köhler theory (Petters and Kreidenweis, 2007). In the next step, we investigated the effect of this hygroscopic growth on aerosol particle optical properties by coupling the hygroscopic model to a Mie scattering model (Wiscombe, 1979). Finally, a radiative transfer model (Santa Barbara Disort Atmospheric Radiation Transfer, SBDART; Ricchiazzi et al., 1998) was used to look into the local effect of hygroscopicity on direct radiative effects of aerosol particles. A scheme of the models and their required inputs is 
Table 1. Enhancement factors $f(\mathrm{RH})$ reported in previous studies.

\begin{tabular}{|c|c|c|c|c|}
\hline Reference & $f(\mathrm{RH})$ & $\mathrm{RH}$ & Site & Time period \\
\hline Carrico et al. (2000) & $1.46 \pm 0.1$ & $82 \%$ & Sagres, Portugal & Jun-Jul 1997 \\
\hline Eldering et al. (2002) & $1.5-2$ & ambient & Kaashidhoo Island, Republic of Maldives & Feb 1999 \\
\hline Fierz-Schmidhauser et al. (2010a) & $1.2-3.3$ & $85 \%$ & Jungfraujoch, Switzerland & May 2008 \\
\hline Fierz-Schmidhauser et al. (2010b) & $\begin{array}{l}2.22 \pm 0.17 \text { (clean marine) } \\
1.77 \pm 0.31 \text { (polluted air) }\end{array}$ & $85 \%$ & Mace Head, Ireland & Jan-Feb 2009 \\
\hline Fitzgerald et al. (1982) & factor of 3.5 (size range: $30-80 \mathrm{~nm}$ ) & $30-95 \%$ & Washington, DC & Jul 1979 \\
\hline Kim et al. (2006) & $2.75 \pm 0.38$ & $85 \%$ & Gosan, Korea & Apr 2001 \\
\hline Kotchenruther et al. (1998) & $1.01-1.51$ & $80 \%$ & Brazil & \\
\hline Liu et al. (2008) & $\begin{array}{l}2.04 \pm 0.28 \text { (urban) } \\
2.29 \pm 0.28 \text { (mixed) } \\
2.68 \pm 0.59 \text { (marine) }\end{array}$ & $80 \%$ & Guangzhou city, China & Jul 2006 \\
\hline Nessler et al. (2005) & $\begin{array}{l}1.2-2.7 \text { (summer) } \\
1.4-3.8 \text { (winter) }\end{array}$ & $85 \%$ & Jungfraujoch, Switzerland & \\
\hline Sheridan et al. (2001) & $1.0-3.3$ & $85 \%$ & North Oklahoma & 1999 \\
\hline Zieger et al. (2010) & $3.24 \pm 0.63$ & $85 \%$ & Zeppelin station, Ny-Ålesund, Svalbard & Jul-Oct 2008 \\
\hline Zieger et al. (2011) & $\begin{array}{l}3.38 \pm 0.31 \text { (maritime) } \\
1.86 \pm 0.17 \text { (continental) } \\
1.95 \pm 0.14 \text { (maritime polluted) }\end{array}$ & $85 \%$ & Cabauw & Jun-Oct 2009 \\
\hline Zieger et al. (2014) & $2.77 \pm 0.37$ (continental) & $85 \%$ & Melpitz & Feb-Mar 2009 \\
\hline Current study & $\begin{array}{l}3.84 \pm 0.37 \\
4.30 \pm 2.26\end{array}$ & $\begin{array}{l}85 \% \\
\text { ambient }\end{array}$ & Zeppelin station, Ny-Ålesund, Svalbard & 2008 \\
\hline
\end{tabular}

shown in Fig. 2. All the input data were taken from the year 2008 from which an extensive set of chemico-physical observations was available. The three models are described in more detail in the following subsections.

\subsection{Hygroscopic growth model}

If the atmospheric RH is high enough, aerosol particles containing soluble material are capable of absorbing water, thus becoming saturated aqueous solution droplets (Seinfeld and Pandis, 1998). The hygroscopicity of an aerosol particle is defined by its growth factor (GF), which is the ratio between the aerosol particle diameter after absorbing water (i.e., the wet droplet diameter), and its dry diameter. Water uptake of an aerosol particle can be modeled by the $\kappa$-Köhler theory assuming thermodynamic equilibrium between atmospheric water vapor and the aerosol particle, where the aerosol water uptake is represented with a single hygroscopicity parameter, $\kappa$. Typical values of $\kappa$ vary from 0 for nonhygroscopic components to about 1.4 for highly hygroscopic salts such as sodium chloride (Petters and Kreidenweis, 2007). According to the $\kappa$-Köhler theory, the saturation ratio $(S)$ over a solution droplet is related to the ambient $\mathrm{RH}$ and can be described by

$$
S\left(D_{\mathrm{p}}\right)=\frac{\mathrm{RH}}{100}=\frac{D_{\mathrm{p}}^{3}-D_{\mathrm{d}}^{3}}{D_{\mathrm{p}}^{3}-D_{\mathrm{d}}^{3}(1-\kappa)} \exp \left(\frac{4 \sigma_{\mathrm{s} / \mathrm{a}} M_{\mathrm{w}}}{\mathrm{RT} \rho_{\mathrm{w}} D_{\mathrm{p}}}\right),
$$

where $D_{\mathrm{d}}(\mathrm{m})$ is the dry diameter of the aerosol particle, $D_{\mathrm{p}}$ (m) is the wet diameter, $\rho_{\mathrm{w}}\left(\mathrm{kg} \mathrm{m}^{-3}\right)$ is the density of water, $M_{\mathrm{w}}\left(\mathrm{kg} \mathrm{mol}^{-1}\right)$ is the molar mass of water, $T$ is the temperature, $R$ is the universal molar gas constant and $\sigma_{\mathrm{s} / \mathrm{a}}$ is equal to the surface tension of the solution/air interface. In the following the surface tension of pure water $0.072 \mathrm{Jm}^{2}$ was applied.
The total hygroscopicity parameters $\kappa$ for the multicomponent aerosol particles considered in this study were calculated using the simple mixing rule:

$\kappa=\sum_{i} \varepsilon_{i} \kappa_{i}$.

$\varepsilon_{i}$ and $\kappa_{i}$ are the volume fraction and hygroscopicity parameter of each component, respectively. $\mathrm{RH}$ values above $95 \%$ were fixed as $95 \%$ in the calculations, due to the uncertainties in the measurements at high values. This might lead to a small negative bias in the GFs at high RHs.

\subsection{Mie model}

Aerosol optical properties such as extinction coefficient (scattering + absorption) are functions of particle size, chemical composition (which defines the complex refractive index of the particle) and the wavelength of the incident light (Ouimette and Flagan, 1982). The interaction of a single spherical particle with radiation can be computed from the Mie theory (Van de Hulst, 1957; Kerker, 1969; McCartney, 1976). In the present study, the Mie model, MIEV0 by Wiscombe (1979) was used. The entire package of numerical code is available from the internet server http://www.scattport.org/index.php/ light-scattering-software?start=100. The Mie model was run for the whole year of 2008 with input as defined in Fig. 2, assuming aerosol particles as homogenously mixed spheres. Two base cases were investigated: the "Dry" base case where $\mathrm{RH}$ was assumed to be 0 (and GF $=1$ ), and the "Wet" base case using ambient $\mathrm{RH}$ and the corresponding hygroscopic growth factors (see Table 2). 


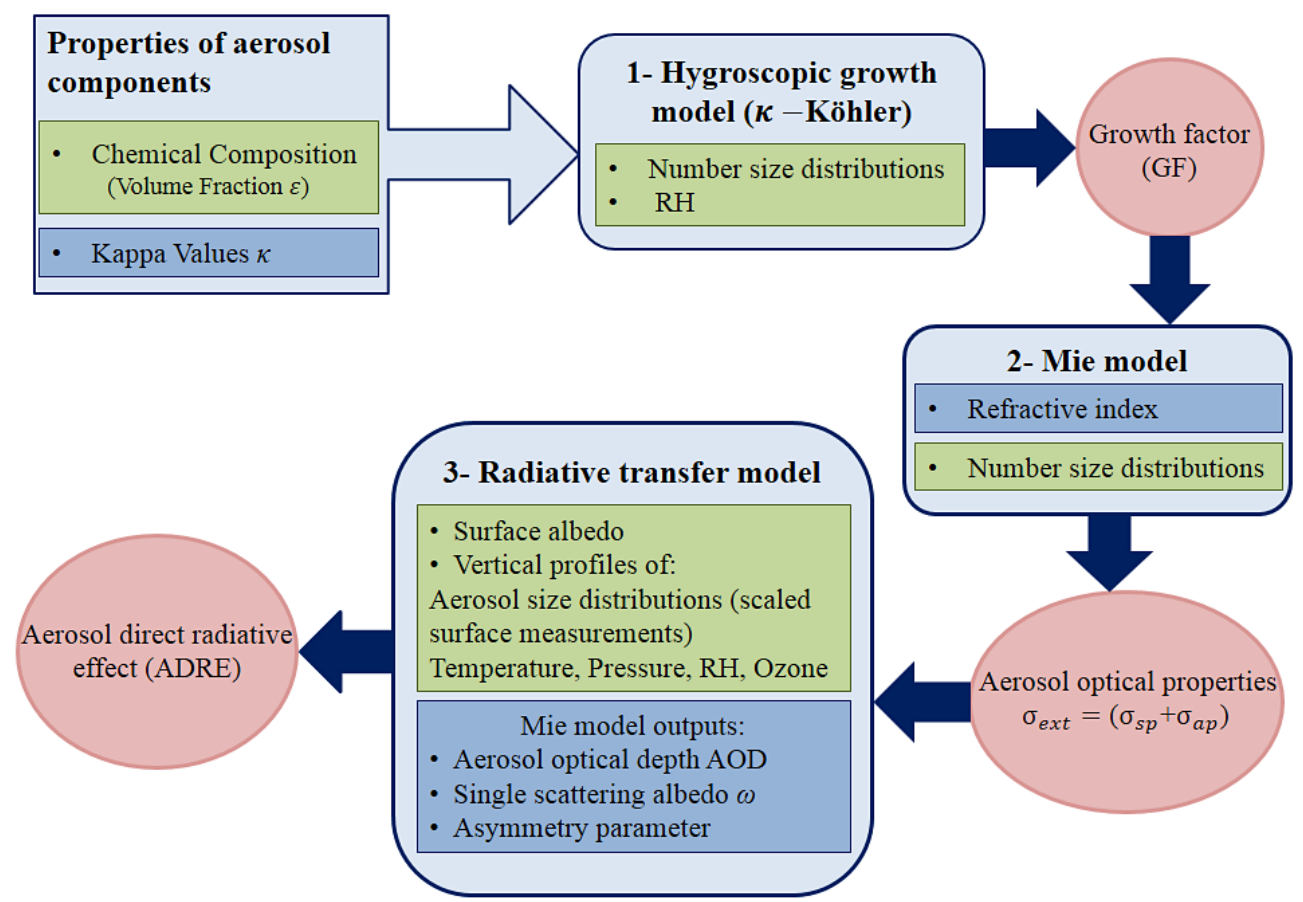

Figure 2. Scheme of the models and their required input, starting with the hygroscopic growth model and ending with the radiative transfer model to calculate the ADRE. The light blue boxes refer to the different model calculations, the green boxes to experimental input data, the dark blue boxes to additional input data (e.g., from literature), and the red circles denote model output.

Table 2. The Dry and Wet base cases used in the model calculations. Please note that some of the individual chemical components are available on a monthly basis only (see text for details).

\begin{tabular}{llll}
\hline & Chemical composition & $\mathrm{RH}$ & Particle size distribution \\
\hline Wet case & Daily mean & Hourly mean & Hourly mean \\
Dry case & Daily mean & $\mathrm{RH}=0 \%$ & Hourly mean \\
\hline
\end{tabular}

\subsection{Radiative transfer model}

The Santa Barbara DISORT (discrete ordinate) Atmospheric Radiative Transfer model was used to calculate the solar irradiance for clear sky conditions (SBDART; Ricchiazzi et al., 1998). The investigated wavelength range covers $0.25-$ $4 \mu \mathrm{m}$ using a wavelength increment of $0.005 \mu \mathrm{m}$. The radiative transfer model requires the atmospheric profiles of pressure $(\mathrm{hPa})$, temperature $(\mathrm{K})$, water vapor density $\left(\mathrm{g} \mathrm{m}^{-3}\right)$ and ozone density $\left(\mathrm{g} \mathrm{m}^{-3}\right)$ (see Sect. 4.1.3 for more information). In the current setup the model also requires specification of the aerosol optical depth (AOD), single scattering albedo $\omega$ and the asymmetry parameter $g$ of the phase function at each atmospheric layer. These parameters were calculated using the Mie model (see Sect. 3.2) over the indicated wavelength range. The solar zenith angle was predefined in the code according to the time of the day, time of year and geographical coordinates.
Instantaneous ADRE $\left(\mathrm{W} \mathrm{m}^{2}\right)$ can be calculated from the outputs provided by the SBDART model. Herein, we designate a perturbation of net (downward minus upward) radiant energy by total aerosol (natural plus anthropogenic) on the surface as ADRE while the direct radiative forcing (RF) only considers the anthropogenic components (see IPCC, 2013). A positive radiative effect indicates addition of energy to the Earth system (i.e., a warming effect) whereas a negative effect indicates a net loss of energy (i.e., a cooling effect). Daily values of the ADRE were calculated based on the Dry and Wet base case calculations (see Table 2) from 08:00 to 12:00 local time (LT; to correspond to the timing of the RH soundings) for 6 days (1st, 5th, 10th, 15th, 20th, 25 th) of each month. We focused on the radiative forcing in the morning due to the availability of the RH soundings which were reported from around 10:00 to 12:00 LT for each day. Monthly averages based on these six values were constructed from March to September, which were the months with sufficient sunlight available. These are the months with 
daytime solar radiation higher than a threshold of $10 \mathrm{~W} \mathrm{~m}^{-2}$ (see Sect. 4.1.4 for more details).

\section{Experimental data}

In the following subsections we describe the measurements used as inputs for the models (see Fig. 2, Sect. 4.1) or model evaluation (Sect. 4.2).

\subsection{Model input data}

\subsubsection{Aerosol number size distribution and relative humidity measurements}

The aerosol number size distribution measurements (between 10 and $790 \mathrm{~nm}$ ) have been conducted since March 2002 at Mt Zeppelin (Tunved et al., 2013), using a closed loop differential mobility particle sizer (DMPS) with a medium size Hauke differential mobility analyzer (DMA) (Knutson and Whitby, 1976; Jokinen and Makela, 1997). The particles are counted using a condensation particle counter (TSI3010). In the present study, 1 year (2008) of hourly averaged aerosol number size distributions was used. The surface ambient $\mathrm{RH}$ measurements were obtained on an hourly basis using the relative humidity sensor 3445-Aanderaa (sensor operated by NILU).

\subsubsection{Aerosol chemical composition}

To calculate the hygroscopic growth of aerosol particles, aerosol chemical composition determined from filter measurements was used. Chemical speciation was made using two different observational data sets: one for the division between organic and elemental carbon (OC / EC) and inorganic aerosol components, and one for attaining the composition of the inorganic aerosol fraction.

First, aerosol particles $\left(D_{\mathrm{d}}<10 \mu \mathrm{m}\right)$ were collected at the Zeppelin station on a monthly basis from 1 September 2007 to 9 September 2008, using a Sierra Andersen (Sierra Instruments Inc.) high-volume sampler equipped with a $\mathrm{PM}_{10}$ inlet and operating with an air flow rate of approximately $1.7 \mathrm{~m}^{3} \mathrm{~min}^{-1}$. Whatman quartz filter sheets grade QM-A of $20 \mathrm{~cm} \times 25 \mathrm{~cm}(8 \mathrm{in} . \times 10 \mathrm{in}$.) were used. All filters were preheated to $800^{\circ} \mathrm{C}$ over 12 hours before sampling. Filters were extracted in $200 \mathrm{~mL}$ of Milli-Q water and $6 \%$ of the extract was removed for H-TDMA (hygroscopic tandem differential mobility analyzer) analysis. The filter samples were analyzed for the OC / EC concentration using a Sunset Laboratories thermo-optical transmittance carbon aerosol analysis instrument (Wallén et al., 2010).

Subsamples of each filter $\left(1.5 \mathrm{~cm}^{2}\right)$ were analyzed for OC / EC before and after extraction in Milli-Q water $\left(2 \mathrm{~mL} \mathrm{~cm}^{-2}\right)$. The OC remaining on the filter after extraction was considered as less water soluble OC (LWS-OC). The difference of the amount of $\mathrm{OC}$ between nonextracted and the

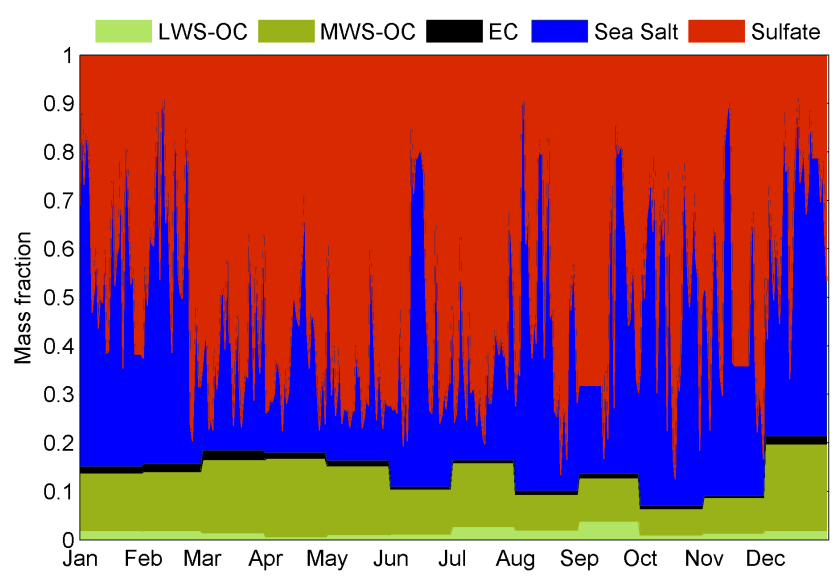

Figure 3. The averaged chemical composition for year 2008 at the Zeppelin station based on filter measurements, on a daily basis for inorganics (sea salt and sulfate) and monthly basis for organics (LWS-OC, MWS-OC, EC).

extracted filter subsamples is an indirect way to measure the water soluble organic carbon, and was denoted as more water soluble organic carbon (MWS-OC). MWS-OC was also determined directly on subsamples of the $200 \mathrm{~mL}$ water extracts and an average of the methods was used in the following work (Silvergren et al., 2014). These analyses provided us with the monthly mass fraction of inorganics, MWS-OC, LWS-OC and EC. The OC / EC composition for the period from 10 September 2008 to 31 December 2008 was assumed to be the same as for the corresponding period during the previous year.

In the next step, the inorganic fraction was assumed to consist of a sulfate $\left(\mathrm{NO}_{3}^{-}, \mathrm{NH}_{4}^{+}, \mathrm{SO}_{4}^{2-}, \mathrm{Ca}^{2+}, \mathrm{K}^{+}\right)$and a sea salt $\left(\mathrm{Na}^{+}, \mathrm{Cl}^{-}, \mathrm{Mg}^{2+}\right)$ fraction. The fractions were determined using daily samples, collected with an open face filter pack system (no particle size cutoff, but shielded by a cylinder, which reduces the sampling efficiency of particles larger than $10 \mu \mathrm{m}$ ) and analyzed by ion chromatography (Hjellbrekke and Fjæraa, 2010; Aas et al., 2009; Ström et al., 2003).

The final chemical aerosol components are thus OC (divided into MWS-OC and LWS-OC), sulfate, sea salt and EC. The physical and chemical properties of these components needed as input in the model calculations are presented in Table 3. For sulfate and sea salt we assumed the properties of ammonium sulfate and sodium chloride, respectively. The averaged chemical composition (Fig. 3) is dominated by inorganics; the contribution of EC to aerosol composition is very small $(<2 \%)$ throughout the year. This implies that the aerosol light extinction is dominated by the scattering over the absorbing component (see the refractive indices of the chemical components in Table 3 ).

Besides assuming the $\mathrm{OC} / \mathrm{EC}$ division to be similar in the falls of 2008 and 2007, internally mixed aerosol particles with homogenous chemical composition over the whole 
Table 3. Density $(\rho)$, hygroscopicity parameter $(\kappa)$ and refractive index (at $550 \mathrm{~nm}$ ) for considered chemical components.

\begin{tabular}{llll}
\hline Component & $\rho\left(\mathrm{g} \mathrm{cm}^{-3}\right)$ & $\kappa$ & Refractive index $(550 \mathrm{~nm})$ \\
\hline Sulfate (ammonium sulfate) & $1.77^{\mathrm{a}}$ & $0.53^{\mathrm{d}}$ & $1.43+1 \times 10^{-8} i^{\mathrm{f}}$ \\
Sea salt (sodium chloride) & $2.17^{\mathrm{a}}$ & $1.12^{\mathrm{d}}$ & $1.50+1 \times 10^{-8}{ }_{i}^{\mathrm{f}}$ \\
More water soluble organics (MWS-OC)* & $1.56^{\mathrm{b}}$ & $0.27^{\mathrm{d}}$ & $1.53+6 \times 10^{-3} i^{\mathrm{f}}$ \\
Less water soluble organics (LWS-OC) & $1.50^{\mathrm{c}}$ & $0.10^{\mathrm{d}}$ & $1.53+8 \times 10^{-3} i^{\mathrm{f}}$ \\
Elemental carbon (EC) & $1.80^{\mathrm{e}}$ & 0.00 & $1.74+6 \times 10^{-1}{ }^{\mathrm{g}}$ \\
\hline
\end{tabular}

* Mean value for glutaric acid, malonic acid and levoglucosan. ${ }^{a}$ Svenningsson et al. (2006); ${ }^{\mathrm{b}}$ Koehler et al. (2006), Svenningsson et al. (2006); ${ }^{\mathrm{c}}$ Engelhart et al. (2008); ${ }^{\mathrm{d}}$ Petters and Kreidenweis (2007); ${ }^{\mathrm{e}}$ Schkolnik et al. (2007); ${ }^{\mathrm{f}}$ Hess et al. (1998), refractive indices as a function of wavelength from the OPAC database were used in calculations. ${ }^{g}$ Chang and Charalampopoulos (1990), refractive index as a function of wavelength was used in calculations.

size range were assumed. While these are certainly simplifications, it has been shown in previous studies that Arctic aerosol particles at Ny-Ålesund, Svalbard, are largely internally mixed, at least in March and April (Covert and Heintzenberg, 1993; Engvall et al., 2009). Also, as shown later in this work, the size dependence of the chemical composition does not appear to be a major factor dominating the optical properties and the direct radiative effect of the aerosol.

\subsubsection{Vertical profiles}

Atmospheric profiles of pressure, temperature, $\mathrm{RH}$ and ozone were estimated using a combination of available daily routine radio soundings performed at Ny-Ålesund by the Alfred Wegener Institude (AWI) and standard atmospheric profiles for polar summer and polar winter (http://www.atm.ox.ac.uk/ RFM/atm). The SBDART model is divided into 60 vertical levels. For the first 40 levels the increment is $0.5 \mathrm{~km}$, and above this the increment is $20 \mathrm{~km}$ for each layer. By using linear interpolation, the various profiles were harmonized to match the vertical levels used in SDBART.

Since no direct measurements on the vertical profiles of aerosol particle number size distributions were conducted in Ny-Ålesund, we assumed a vertical-scale factor that relates the aerosol number concentrations at a given altitude to the surface measurements (at $474 \mathrm{~m}$ a.s.1.). The vertical profile of the aerosol particle number size distribution was estimated based on mean extinction coefficient profiles obtained from observations with the spaceborne Cloud-Aerosol Lidar and Infrared Pathfinder Satellite Observations (CALIPSO) lidar over the Arctic (Di Pierro et al., 2013). Winker et al. (2013) present Arctic extinction profiles that show an exponential decrease with height. The Zeppelin observations were considered as being representative for the lowermost kilometer of the atmospheric column. Above this height, we scaled the in situ findings by assuming an exponential decay in aerosol concentration with height. This leads to a scale factor that is unity at the height of the Zeppelin station and decreases exponentially to zero at $10 \mathrm{~km}$ height. The chemical composition was kept the same for all vertical layers.

\subsubsection{Surface albedo}

Surface albedo data were taken from ground-based measurements at Ny-Ålesund using CMP11 pyranometers at $11 \mathrm{~m}$ a.s.l. (http://doi.pangaea.de/10.1594/PANGAEA. 808703). During the polar night which starts and ends around mid-October and mid-February, respectively, no albedo measurements were available. Data was further reduced by only allowing measurements exceeding $10 \mathrm{~W} \mathrm{~m}^{-2}$. This value is chosen to be approximately five times more than the typical variation from the instrument's zero point. The daily mean values for the year 2008, from March to September, were used as input to SBDART.

\subsection{Model evaluation data}

\subsubsection{H-TDMA measurements of aerosol particle hygroscopic growth}

The hygroscopic growth calculations were evaluated using data collected with an H-TDMA between September 2007 and August 2008. TDMA was first introduced by Liu et al. (1978) as a technique to study the change in particle diameter as a response to changes in surrounding conditions (i.e., temperature or humidity). H-TDMA instruments have successfully been used in a multitude of studies to investigate particle size changes associated with changes in humidity (e.g., Sekigawa, 1983; McMurry and Stolzenburg, 1989; Swietlicki et al., 2008; Nilsson et al., 2009; Achtert et al., 2009). In the current study, water extracts of the monthly filter samples of aerosol particles were analyzed by an $\mathrm{H}-$ TDMA by atomizing the extracts and measuring the hygroscopic growth factor of the dried 80, 90, 100, 110 and $120 \mathrm{~nm}$ particles. Note that the growth factors inferred from the $\mathrm{H}$ TDMA measurements do not represent the size-dependent chemical composition at the Zeppelin site, but rather an average bulk composition. During the measurements, the humidity was set to approximately $90 \% \mathrm{RH}$ in the second DMA, and the temperature was set to $293.15 \mathrm{~K}$. Each scan took $300 \mathrm{~s}$ and at least four scans were averaged for each size bin (Silvergren et al., 2014). 


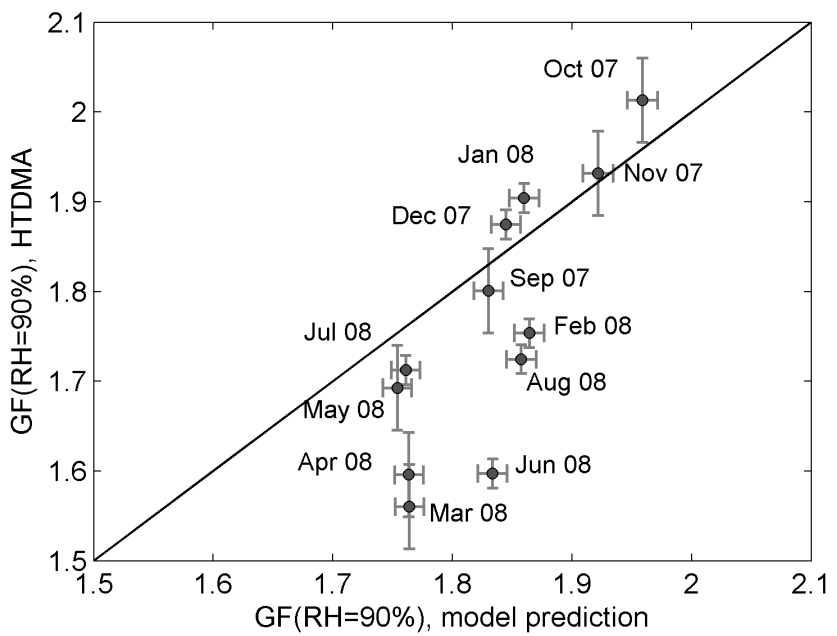

Figure 4. Comparison of calculated monthly growth factors using the hygroscopic model and the sampled H-TDMA measurements at $\mathrm{RH}=90 \%$ for aerosol particles in the size range of $80-120 \mathrm{~nm}$, from September 2007 to August 2008.

\subsubsection{Dry scattering coefficient}

The Mie calculations (see Fig. 2) for dry aerosol particles were evaluated using data from a 3-wavelength integrating nephelometer (TSI Inc., model 3563) operated at wavelengths of 450, 550, and $700 \mathrm{~nm}$ (Anderson et al., 1996) throughout the year 2008 at almost dry conditions, with the RH inside the instrument below $20 \%$. The scattering coefficients were averaged over $10 \mathrm{~min}$.

\subsubsection{Wet scattering coefficient}

A field campaign was carried out at the Zeppelin station from 15 July to 12 October 2008, where a humidified nephelometer, hereafter referred to as the wet nephelometer, was used to measure light scattering coefficients at 450,550 , and $700 \mathrm{~nm}$. The RH was changed in the instrument between 20 and $95 \%$ (Zieger et al., 2010; Fierz-Schmidhauser et al., 2010b). The wet nephelometer measurements were used to evaluate the Mie model at the humidified conditions. Furthermore, an estimate for the GF was back-calculated from the comparison of predicted scattering enhancement factors $f(\mathrm{RH})$ for different hygroscopic growth factors to the measured values of the humidified nephelometer (see Zieger et al., 2010 for the procedure).

\section{Results and discussion}

\subsection{Model evaluation}

\subsubsection{Monthly H-TDMA growth factor measurements vs. the hygroscopic model}

To evaluate the hygroscopic growth model, monthly growth factor measurements were compared to model calculations for the period September 2007-August 2008 (Fig. 4). The $\mathrm{RH}$ in the model was set to $90 \%$ and the temperature to $293.15 \mathrm{~K}$, i.e., the same as in the H-TDMA setup, and the averaged growth factors for a particle size range of $80-120 \mathrm{~nm}$ were calculated for each month. The model results show a very good agreement with the measurements for autumn and early winter (September-January) with the predicted values within about $2 \%$ of the measurements, but a positive bias of $4-15 \%$ for spring and summer (February-August). The good agreement for fall and winter gives confidence to our assumed chemical composition during this time, and is probably due to the dominance of sea salt in the total $\kappa$ value and thus the GF. During the other months, the sulfate and organic fractions are larger, leading to larger uncertainties in the assumed $\kappa$ values. The large deviation for the June sample is probably due to the fact that the high-volume sampler was out of order during part of June. This period coincided with high sea salt concentrations, causing an apparent difference between the average predicted and measured GFs. The most likely explanation for the other discrepancies are the simplifications we have made regarding the chemical composition. For instance, due to the lack of information on the size dependence of chemical composition, we assumed a homogenous chemical composition over the whole size range. However, the H-TDMA data have been collected using dissolved, atomized and dried filter samples, thus yielding particle size and composition distributions that might be different from those of the ambient aerosol. Furthermore, while the H-TDMA instrument had a size range of 80-120 nm, the filter samples included contributions from considerably larger particles.

Previous studies on the seasonal trends of chemical composition at several monitoring sites with marine influence in the Arctic have shown a winter/early spring increase in sulfate (Radke et al., 1984; Quinn et al., 2007), maximum concentrations of submicrometer sea salt from November to February and maximum concentrations of supermicron sea salt during summer months (Quinn et al., 2002). The hygroscopic growth model is very sensitive to the amount of inorganics due to their relatively high hygroscopicity parameter $\kappa$. Assuming the same relative amount of sea salt and sulfate in all particles throughout the year can explain the overestimation of growth factor calculations by the model for the size range of $80-120 \mathrm{~nm}$ compared to the H-TDMA measurements. Considering these uncertainties, the agreement between the modeled and measured growth factors is reasonable. 

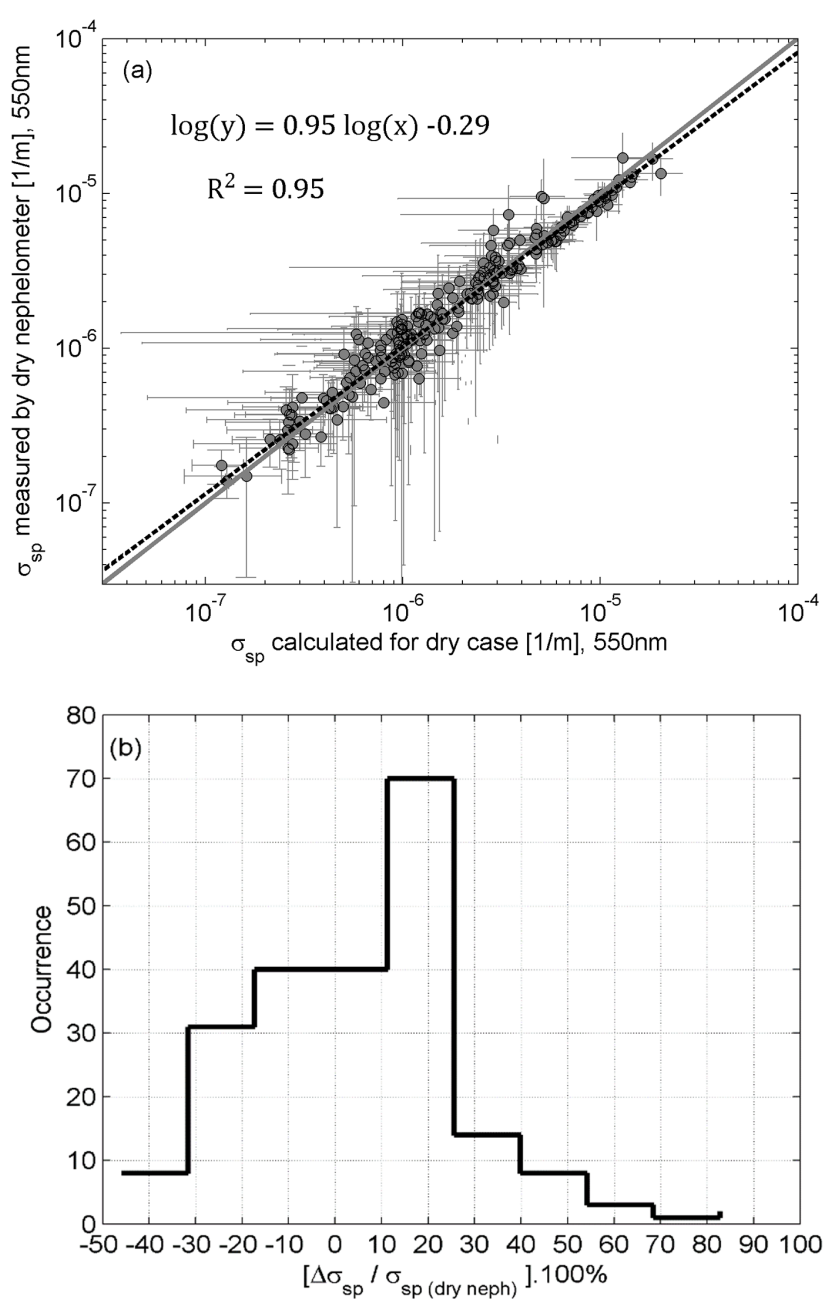

Figure 5. (a) Correlation between modeled and measured daily mean dry $\sigma_{\mathrm{sp}}(550 \mathrm{~nm})$ for the year 2008 . The error bars indicate the standard deviations of the daily averages. (b) Histogram of the deviation of the modeled scattering coefficient from measurements in percentage $(\%)$.

\subsubsection{Dry scattering coefficient measurements vs. the Mie model for the year 2008}

Due to the low contribution of EC (see Fig. 3), typically less than $2 \%$, the aerosol extinction coefficient is in practice equal to the scattering coefficient. The comparison between the dry scattering coefficients calculated with the Mie model for the Dry case (see Table 2) and those measured with the dry nephelometer is presented in Fig. 5a. The modeled and measured scattering coefficients show a good agreement $\left(R^{2}=0.95\right)$. For most of the days the modeled scattering coefficients are within $20 \%$ of the measured values (see Fig. 5b), which gives confidence in modeling the optical properties of the aerosols using the Mie theory.
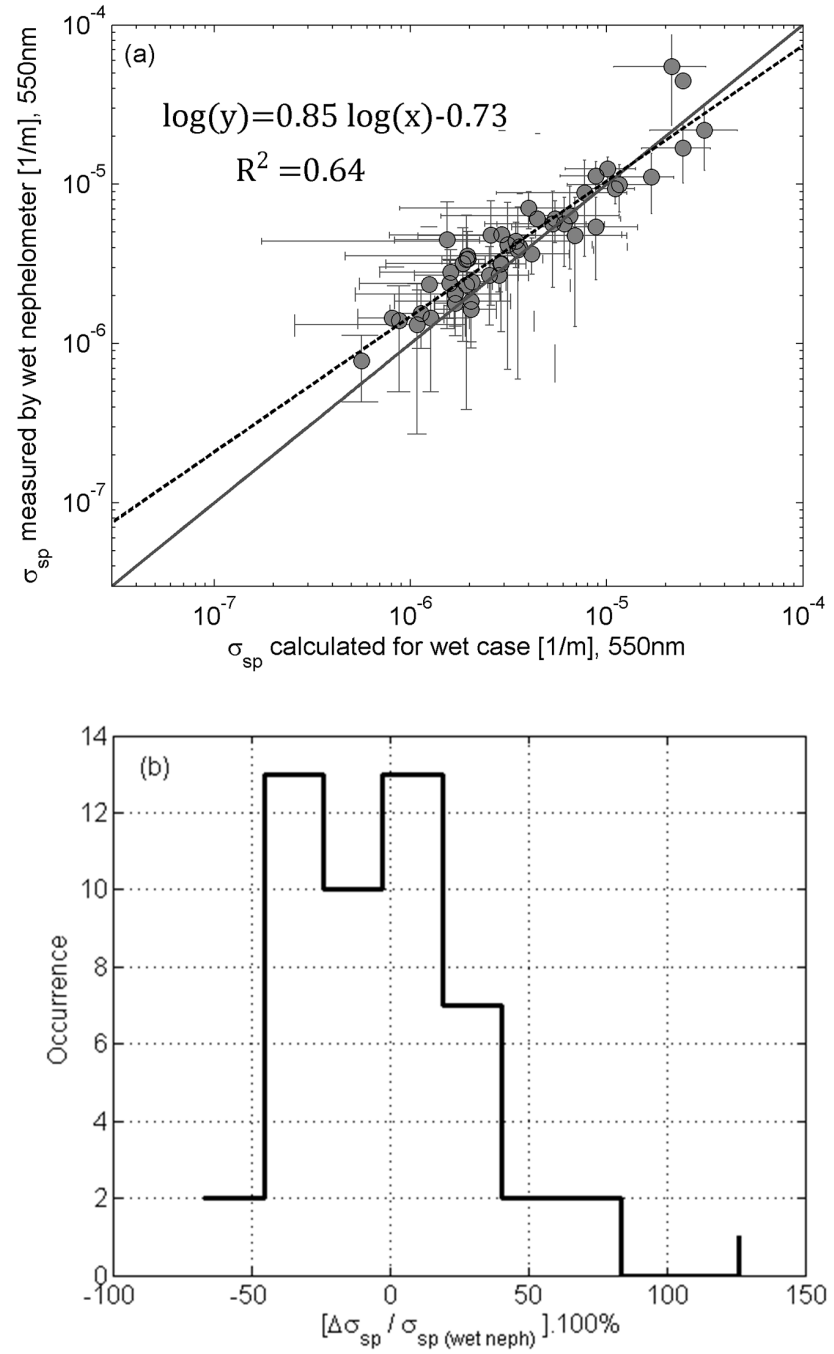

Figure 6. (a) Correlation between modeled and measured daily mean wet $\sigma_{\mathrm{sp}}(550 \mathrm{~nm})$ at the ambient $\mathrm{RH}$ for the campaign (15 July-12 October 2008). The error bars indicate the standard deviations of the daily averages. (b) Histogram of the deviation of modeled scattering coefficient from measurements in percentage $(\%)$.

\subsubsection{Wet scattering coefficient measurements vs. the Mie model during the campaign}

The comparison between the calculated and measured wet scattering coefficients during the campaign is presented in Fig. 6a. The calculated and modeled coefficients show a reasonable agreement with $R^{2}=0.64$. The histogram in Fig. $6 \mathrm{~b}$ shows that for most of the days the deviation between the modeled and measured scattering coefficient is less than $40 \%$, with an average bias of $-10 \%$. This negative bias is probably explained by particles $>790 \mathrm{~nm}$ not covered by the DMPS-based size distribution that we used as an input for the model - thus, particles from the coarse mode are only partly accounted for in the model. 


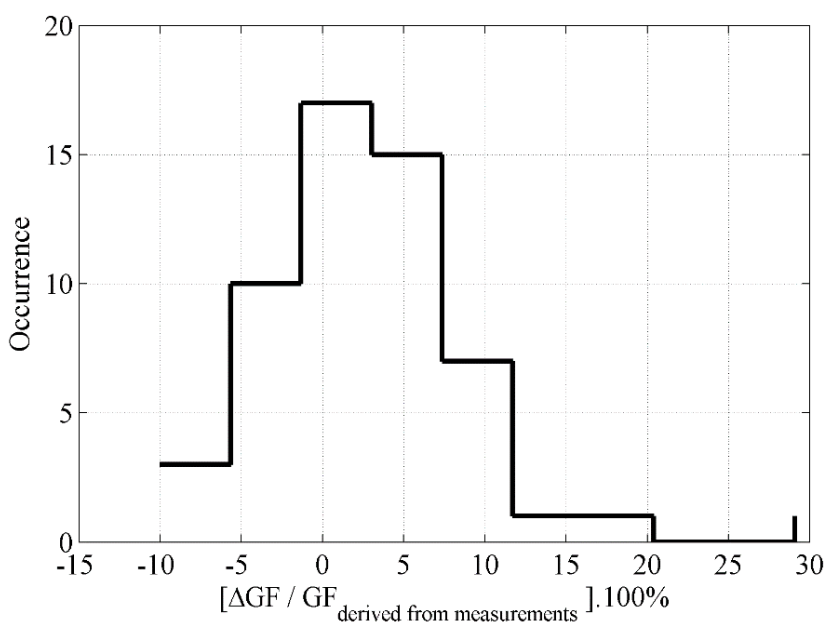

Figure 7. Histogram of modeled growth factor deviations from values derived from the humidified nephelometer measurements in percentage (\%) during the campaign.

The average modeled enhancement factor $f(\mathrm{RH}=85 \%)$ during the campaign period was $4.03 \pm 0.50$ (mean \pm standard deviation), which is higher than $3.24 \pm 0.63$ reported in Zieger et al. (2010). One possible reason for this could be an overestimation of the apparent hygroscopicity (i.e., sea salt only attributed to the fine mode below $790 \mathrm{~nm}$ ) leading to an overestimation of the resulting $f(\mathrm{RH})$ (see also Zieger et al., 2013). Another reason for this bias could be the different dry scattering coefficient data used in the studies. The different dry values can be partly due to the different operating conditions, and partly due to different inlet structures and resulting losses - particularly for the coarse mode. The measured size distribution and dry nephelometer data were taken from instruments connected to the SU (Stockholm University) inlet (without a size cut), while Zieger et al. (2010) performed their measurements on their own inlet (without a size cut). However, their scattering coefficient and size distribution measurements were approximately $25 \%$ higher compared to the SU inlet (see Zieger et al., 2010 for more details).

Zieger et al. (2010) parameterized their measured $f(\mathrm{RH})$ factors by an empirical $\gamma$ fit. In addition, they used their measured $f(\mathrm{RH})$ and size distributions together with an assumption about the dry refractive index to retrieve the apparent hygroscopic growth factors. These growth factors retrieved from the humidified nephelometer measurements were compared to the averaged growth factors (diameter $>100 \mathrm{~nm}$ ), calculated using the hygroscopic growth model (see Fig. 7). The deviation of our model calculations from these retrieved growth factors during the campaign is between -5 and $10 \%$, which is in line with the comparisons to the H-TDMA data.

\subsection{Seasonal variations in 2008}

\subsubsection{Relative humidity and hygroscopic growth factors}

The seasonal variation of the RH measurements and the modeled GFs for the year 2008 are presented in Fig. 8. The RH measurements show no clear seasonal trend, except during March and the beginning of April when average RH values are in general lower $(<80 \%)$ compared to the rest of the year. RH varies significantly not only from day to day but also during the day. The error bars in Fig. 8a indicate the standard deviation for each day. The low RH values coincide with the Arctic haze period (see e.g., Tunved et al., 2013, and references therein) and the smallest sea salt fraction in the particles (see Fig. 3), when polluted air masses from lower latitudes are transported to the Arctic. The annual variability in $\mathrm{RH}$ values during 2008 is similar to observations for other years as well.

The daily averaged GF calculated with the hygroscopic growth model follow the behavior of the RH, as expected (see Fig. 8b). To separate the effect of RH and chemical composition on growth factor calculations, we also looked into the modeled GF at a fixed relative humidity $(85 \%)$ and dry diameter $(200 \mathrm{~nm})$ (see Fig. $8 \mathrm{c}$ ). These results suggest that the particles were less hygroscopic during spring (March-May) as compared with other seasons (June-February). Comparison between Fig. $8 \mathrm{~b}$ and $\mathrm{c}$ shows, however, that while RH is the main parameter controlling the magnitude of the ambient growth factor values, the chemical composition plays an important role in affecting the seasonal variation of the hygroscopic growth.

The annual mean GF (ambient $\mathrm{RH})$ and $\mathrm{GF}(\mathrm{RH}=85 \%)$ averaged over the whole size distribution were calculated to be $1.64 \pm 0.28$ (mean \pm standard deviation) and $1.60 \pm 0.05$, respectively.

\subsubsection{Number size distributions, scattering coefficients and enhancement factors}

Seasonal variations of measured aerosol number size distributions, modeled scattering coefficients $\sigma_{\mathrm{sp}}$ and enhancement factors $f(\mathrm{RH})$ are presented in Fig. 9 .

Figure 9a shows the dominance of particles larger than $100 \mathrm{~nm}$ during the haze period (March-April-May) and high concentrations of particles smaller than $100 \mathrm{~nm}$ during summer (June-July-August). The winter period from October to February displays extremely low particle concentrations. The same type of seasonal variation can be distinguished in size distribution measurements from the Zeppelin station for other years as well (Tunved et al., 2013).

Figure $9 \mathrm{~b}$ shows a clear seasonal variability in dry $\sigma_{\mathrm{sp}}$ calculated by the Mie model, with minimum values during late summer and the beginning of fall (July-August-September). These low values are most likely related to the low concentration of particles larger than $100 \mathrm{~nm}$ in diameter. The summer 

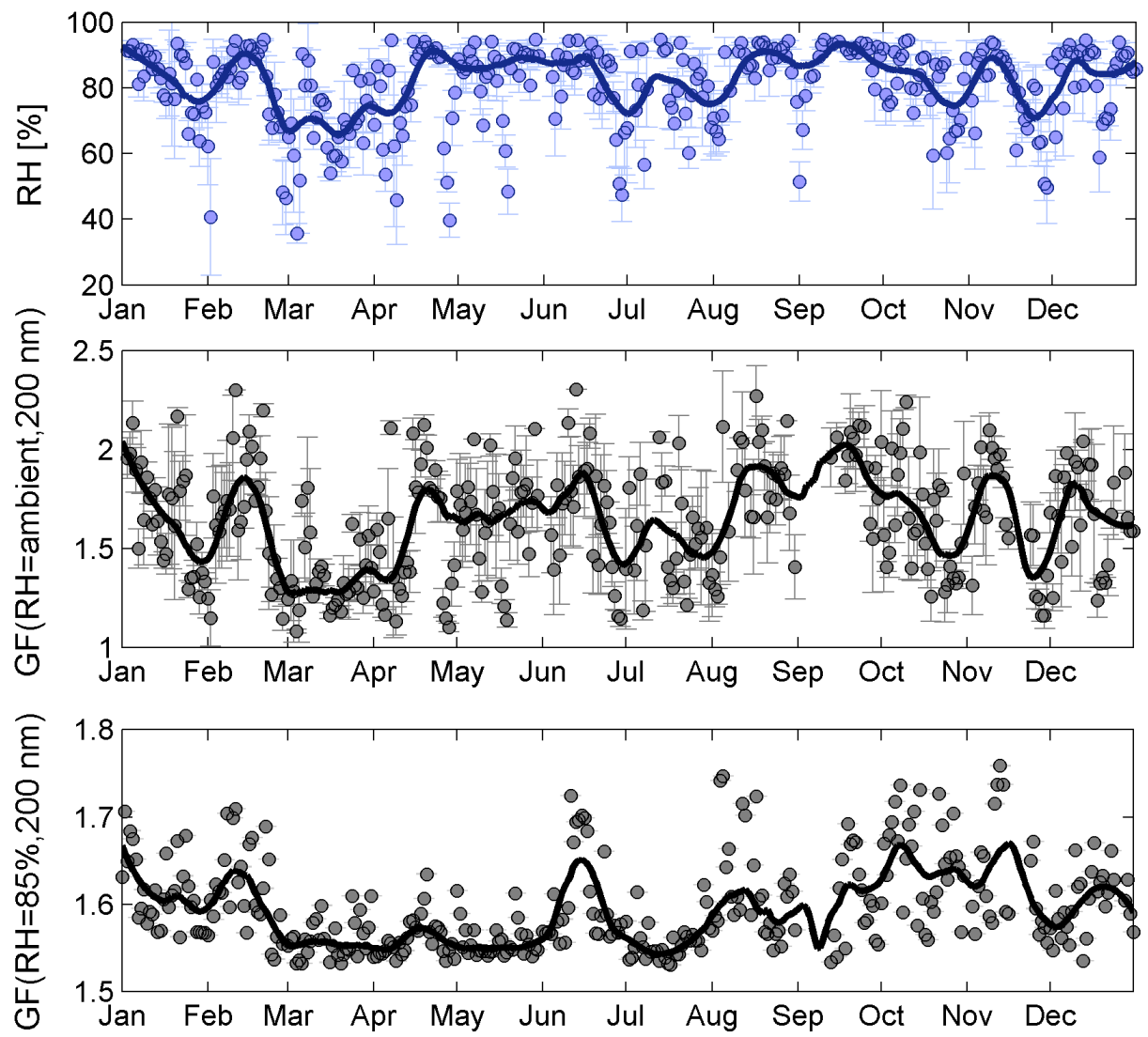

Figure 8. (a) Daily mean relative humidity (\%) measured at the Zeppelin station for year 2008. (b) The calculated daily mean GFs assuming ambient RH for an initial size of $200 \mathrm{~nm}$. (c) The calculated daily mean GFs at RH=85\% for initial size of $200 \mathrm{~nm}$. In Fig. $9 \mathrm{a}$ and b the error bars indicate standard deviations.

is followed by a moderate increase of dry $\sigma_{\mathrm{sp}}$ towards fall and winter. The gradual increase continues until March and is then followed by a more abrupt increase. The maximum dry scattering is observed during March, April and May, associated with the increase in number concentration of larger particles (diameter $>100 \mathrm{~nm}$ ). The overall seasonal changes in the scattering coefficients are similar for the wet (ambient $\mathrm{RH})$ and the dry $(\mathrm{RH}=0 \%)$ cases, except for late August and early September when the wet $\sigma_{\mathrm{sp}}$ is almost as high as during March, April and May.

The enhancement factor $f$ (ambient $\mathrm{RH}$ ) displays less distinct seasonal variation than both dry and wet scattering coefficients (see Fig. 9c) although there is a tendency of systematically lower values during March to early April. These low values coincide with both less hygroscopic aerosol particles and lower values of atmospheric RH as compared with the rest of the year, along with the dominance of larger particles over smaller particles. To separate the effects of $\mathrm{RH}$ and chemical composition, enhancement factors were also calculated for a fixed RH ( $85 \%)$. Like $f$ (ambient $\mathrm{RH}$ ), $f(\mathrm{RH}=85 \%)$ is lower during the haze period as compared with the summer and early fall (see Fig. 9d). Comparison between $f(\mathrm{RH}=85 \%)$ and $f($ ambient $\mathrm{RH})$ values shows the large impact of $\mathrm{RH}$ variation. The seasonal trends in $\sigma_{\mathrm{sp}}$ and $f(\mathrm{RH}=85 \%)$ show an anti-covariation during the haze period, with the largest values of $\sigma_{\mathrm{sp}}$ and lowest values of $f(\mathrm{RH}=85 \%)$ (Fig. 9b, d). The calculated annual average $f(\mathrm{RH}=85 \%)$ and $f($ ambient $\mathrm{RH})$ values for the year 2008 were $3.84 \pm 0.37$ and $4.30 \pm 2.26$ (mean \pm standard deviation), respectively.

In Zieger et al. (2010), the same relation of a slight decrease in $f(\mathrm{RH}=85 \%)$ with increasing particle size was observed. In that study they found no clear shift in $f(\mathrm{RH})$ during the campaign, while the size and chemical composition clearly changed in time. This was attributed to compensating effects between size and chemical composition: smaller and less hygroscopic particles had the same magnitude in scattering enhancement as larger but more hygroscopic particles like sea salt. 


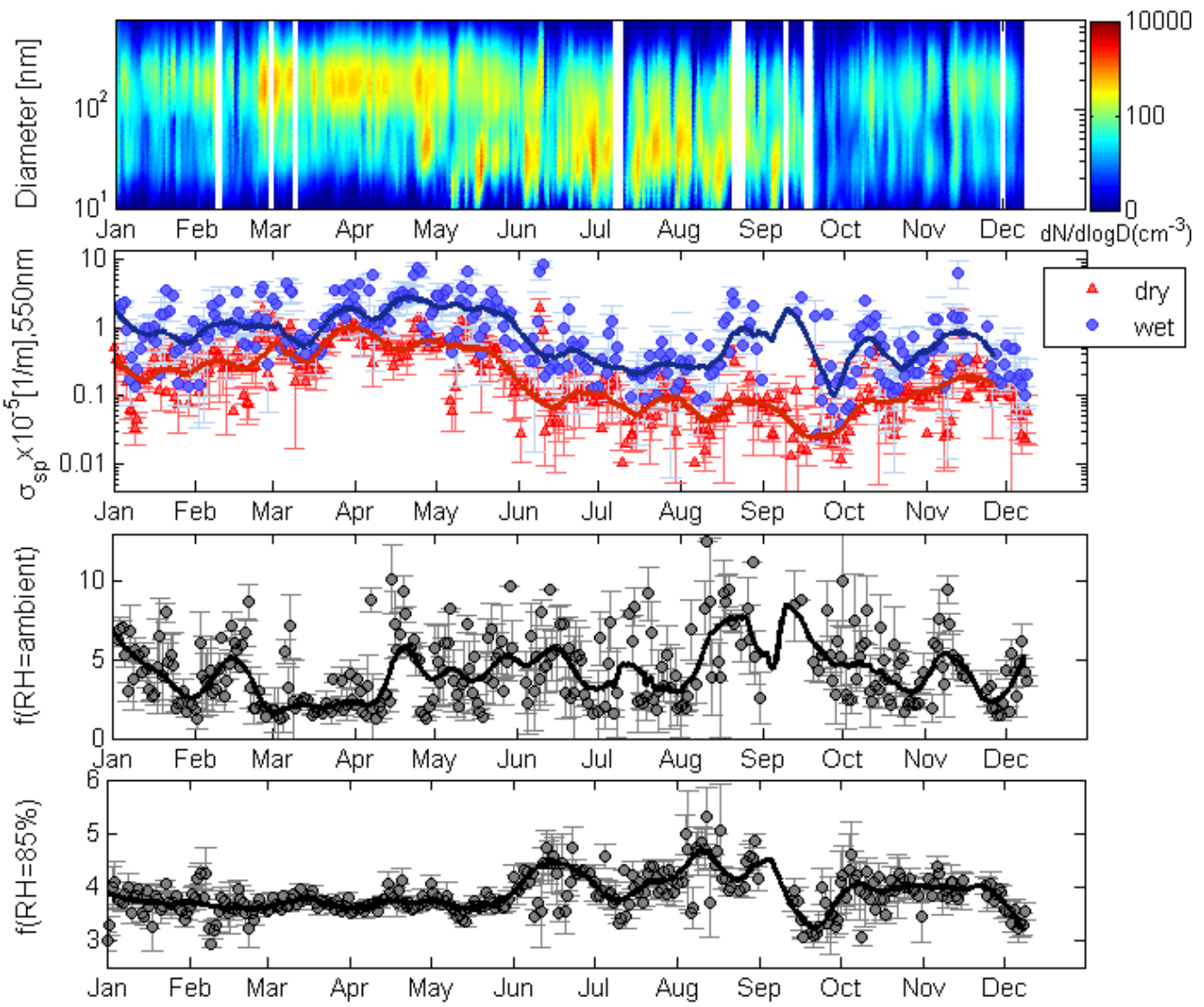

Figure 9. (a) Number size distributions measured at the Zeppelin station for year 2008. (b) The calculated daily mean scattering coefficients for the Dry and Wet cases (see Table 2). (c) The calculated daily mean enhancement factors $f$ (ambient RH) for the Wet case. (d) The four calculated daily mean enhancement factors $f(\mathrm{RH}=85 \%)$. In all figures the error bars indicate standard deviations. Note that the scale is different in (c) and Fig. 10d.

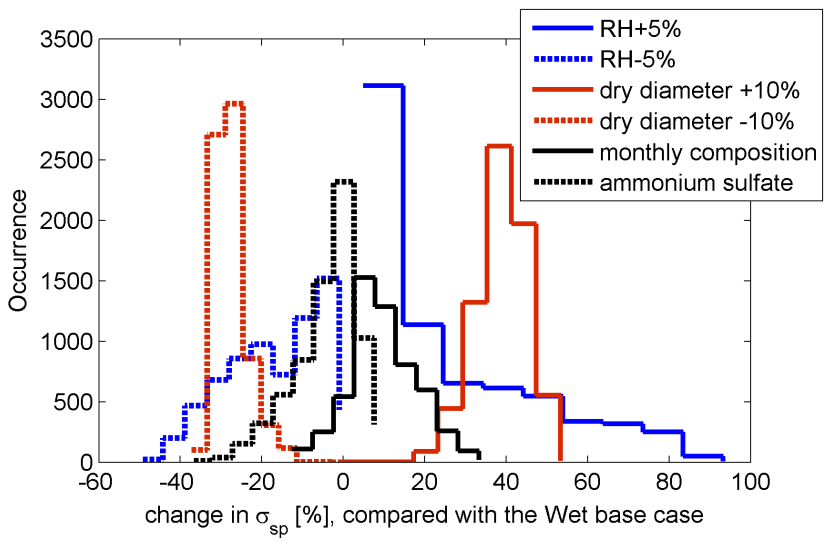

Figure 10. Sensitivity of the hourly calculated $\sigma_{\text {sp }}$ to RH, aerosol dry size and chemical composition as compared with the Wet base case (see Table 2).

\subsubsection{Sensitivity of aerosol light scattering to $\mathrm{RH}$, particle dry size and composition}

The sensitivity of the calculated wet scattering coefficients to RH, particle dry size and composition as compared with the Wet base case (see Table 2) is demonstrated in Fig. 10. The ambient RH was varied by $\pm 5 \%$ of the base values and the particle dry size by $\pm 10 \%$. The sensitivity to the aerosol chemical composition was tested in two ways: the daily averaged chemical compositions were replaced by monthly averaged chemical compositions or by pure ammonium sulfate. Figure 10 shows that the RH and dry size of the particle play the most important roles in determining the scattering coefficient. Increasing the RH by $5 \%$ of the base values, increases the hourly mean values of $\sigma_{\mathrm{sp}}$ by $10-100 \%$, although in most cases the deviation is below $50 \%$. Decreasing the $\mathrm{RH}$ by $5 \%$ decreases the hourly mean values of $\sigma_{\text {sp }}$ by $0-40 \%$. Increasing the initial dry diameter $\left(D_{\mathrm{d}}\right)$ by $10 \%$, increases the hourly mean values of $\sigma_{\mathrm{sp}}$ by $20-50 \%$, and decreasing the size by $10 \%$, decreases the hourly mean values of $\sigma_{\mathrm{sp}}$ by $10-40 \%$. As the whole particle number size distribution is shifted with the factor, changes in the dry diameter are equiv- 

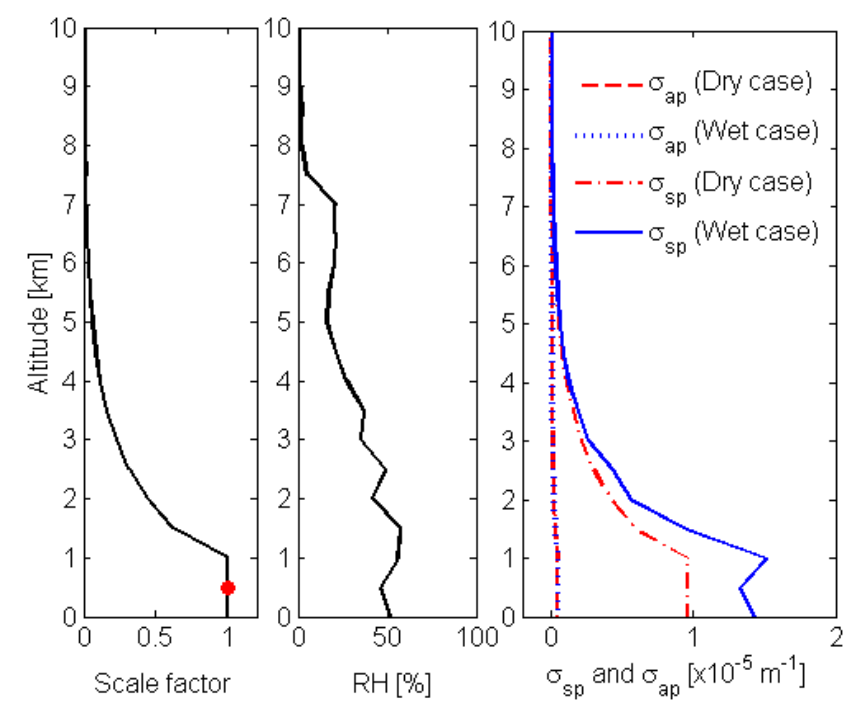

Figure 11. Vertical profile of (a) scale factor for particle number size distributions, the red point shows the level of the station. (b) Ambient RH measured by soundings. (c) $\sigma_{\mathrm{sp}}$ and $\sigma_{\mathrm{ap}} \mathrm{m}^{-1}$, modeled for the Dry and Wet cases for 11 April 2008 at the Zeppelin station.

alent to changing number concentrations of optically active particles. Replacing the daily varying chemical composition of the particles by monthly varying chemical compositions changes the hourly mean values of $\sigma_{\mathrm{sp}}$ by -10 to $30 \%$ and replacing the daily varying chemical composition by pure ammonium sulfate changes the hourly mean values of $\sigma_{\mathrm{sp}}$ by -20 to $10 \%$, with most of the values being between -5 and $5 \%$. The latter result implies that assuming a composition of pure ammonium sulfate in calculations of the optical properties of Arctic aerosol particles results in most cases in a deviation from the true value by only $5 \%$, which is in line with the findings of Zieger et al. (2010) for their summer and fall campaign.

\subsection{Effect of aerosol water uptake on the direct radiative effect of aerosols}

\subsubsection{Vertical profiles for 11 April 2008}

Example vertical profiles of the number size distribution scale factor (see Sect. 4.1.3), RH, scattering coefficient $\left(\sigma_{\mathrm{sp}}\right)$ and absorption coefficient $\left(\sigma_{\mathrm{ap}}\right)$ for 11 April 2008 are presented in Fig. 11a, b, and c, respectively. RH values of about $50 \%$ up to $2 \mathrm{~km}$ and lower values above were measured on this day. A comparison between the absorption coefficients calculated for the Dry and Wet cases shows the negligible impact of $\mathrm{RH}(<1 \%)$ on absorption properties of aerosol particles at the Zeppelin station. In contrast, a significant difference between the scattering coefficients calculated for the Dry and Wet cases is predicted, especially below $2 \mathrm{~km}$ (about $50 \%$ ), where both $\mathrm{RH}$ and the aerosol particle concentrations
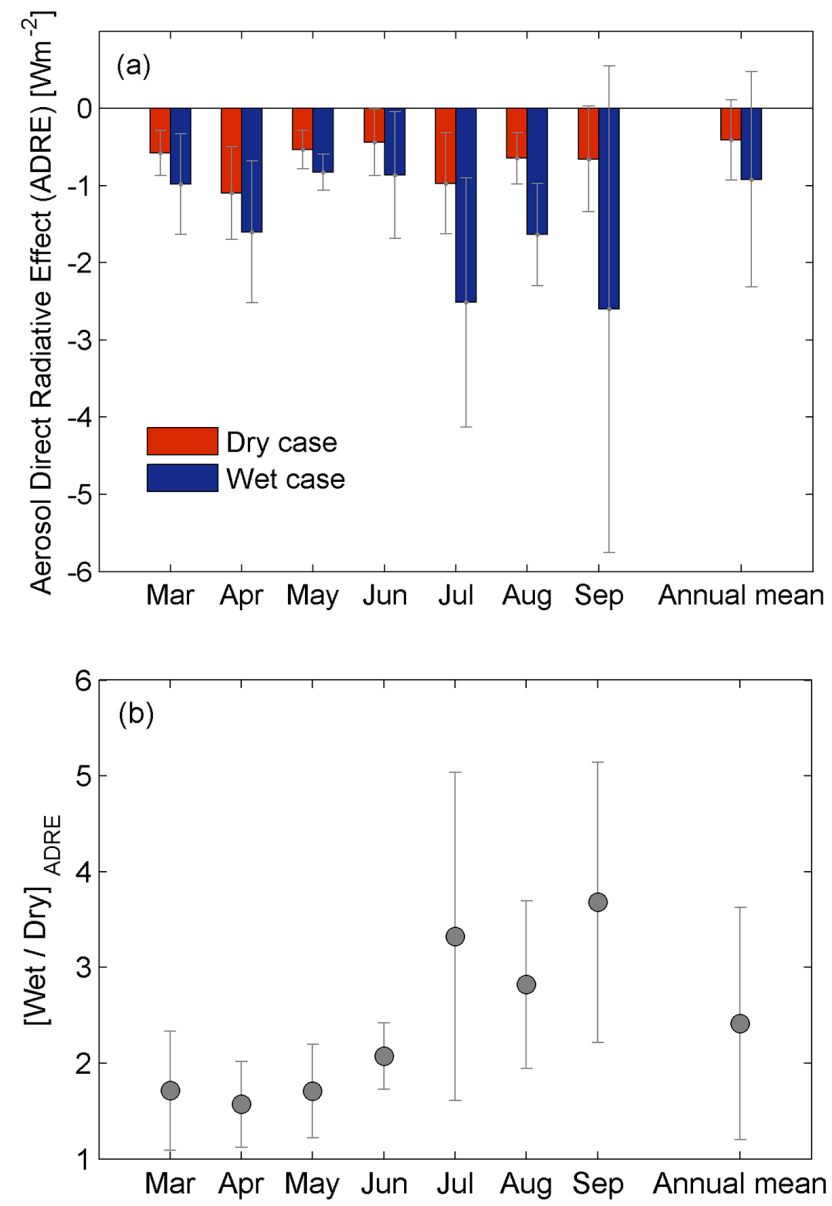

Figure 12. (a) Monthly and annual averaged ADRE for the Dry and Wet cases (see Table 2) at the Zeppelin station for 2008. For the months not shown the ADRE is assumed to be zero due to lack of sunlight. (b) The ratio between Wet and Dry ADRE. The error bars indicate the standard deviations.

are high. The magnitude of the enhancement is comparable to typical values reported by e.g., Zieger et al. (2010). It is worth noting that the surface-level RH on this example day is somewhat towards the lower end of typical values observed in April (see Fig. 8a), so the expected difference between Dry and Wet cases is larger on days with higher RHs.

\subsubsection{Aerosol direct radiative effect}

The comparison between the Dry and Wet monthly and annual averaged ADRE at the surface is presented in Fig. 12a. ADRE is calculated from March to September using the daily mean surface albedo, aerosol number size distribution data, and the vertical profiles described in Sect. 4.1.3. Larger particles backscatter more light (Bohren and Huffman, 1983), which results in less downward solar flux and a cooling effect at the surface. Therefore, the monthly mean ADRE $\left(\mathrm{W} \mathrm{m}^{-2}\right)$ calculated for the Wet case is always more negative than the Dry case and differs from month to month due 
to the changes in solar zenith angle, surface albedo, amount of solar radiation, $\mathrm{RH}$, aerosol composition and number concentration profiles. The values of the monthly mean ADRE vary from -0.44 to $-1.09 \mathrm{~W} \mathrm{~m}^{-2}$ for the Dry case and from -0.83 to $-2.60 \mathrm{~W} \mathrm{~m}^{-2}$ for the Wet case. The dry ADRE peaks in April when the scattering coefficients are highest (see Fig. 9b). The wet ADRE is the highest in July, August and September. Humidity observations in the Arctic troposphere over Ny-Ålesund show highest $\mathrm{RH}$ values below $1 \mathrm{~km}$ during July, August and September as compared with the other months, while there are no significant monthly differences at the higher altitudes $(>1 \mathrm{~km})$ (Treffeisen et al., 2007). The hygroscopic growth of aerosol particles, reflected in the ratio between the wet and dry ADRE, results in about 1.6-3.7 times more negative ADRE at the surface (Fig. 12b), with less impact of RH during the haze period (March-April-May) and higher impact during late summer and early fall (July-August-September). This is reasonable, since the haze period is characterized by less hygroscopic larger (diameter $>100 \mathrm{~nm}$ ) particles, while after the haze period the size distribution shifts to primarily smaller particles (diameter $<100 \mathrm{~nm}$ ), and the overall composition is dominated by sea salt (see Figs. $9 \mathrm{a}, 8 \mathrm{~b}, \mathrm{c}$ ). The annual mean ADRE for the Wet case is $-0.92 \mathrm{~W} \mathrm{~m}^{-2}$, which is more than two times more negative than the Dry case, for which the ADRE is $-0.41 \mathrm{~W} \mathrm{~m}^{-2}$.

It is interesting to note that the seasonal variation of the direct aerosol effect displays a somewhat different behavior from the aerosol scattering coefficients displayed in Fig. 9a, which peak during the haze period. This can be explained by the fact that the ADRE is the combined result of the magnitude of solar insolation, surface albedo and the scattering coefficient and vertical distribution of aerosol particles. The scattering coefficient of the aerosol population is in turn controlled by the particle concentration and the scattering efficiency of the individual particles. The latter is controlled by particle size (governed by their dry size, ambient RH, and hygroscopicity) and refractive index (governed by the chemical composition). Thus, ADRE is a complex function of season, aerosol properties, RH, and surface albedo. While we believe that the seasonal trends in the calculated ADRE values are representative, their exact magnitude is subject to larger uncertainties due to lack of information about the exact vertical distribution of the aerosol particle number concentration, their number size distribution and chemical composition, as well as the missing coarse mode.

\subsection{Sensitivity of ADRE to RH, particle dry size, composition and surface albedo}

The sensitivity of the calculated ADRE to RH, particle size, composition and surface albedo as compared with the Wet base case (see Table 2) is presented in Fig. 13. The variations in RH, particle dry size and composition are the same as those presented in Sect. 5.2.3 and Fig. 10. The surface

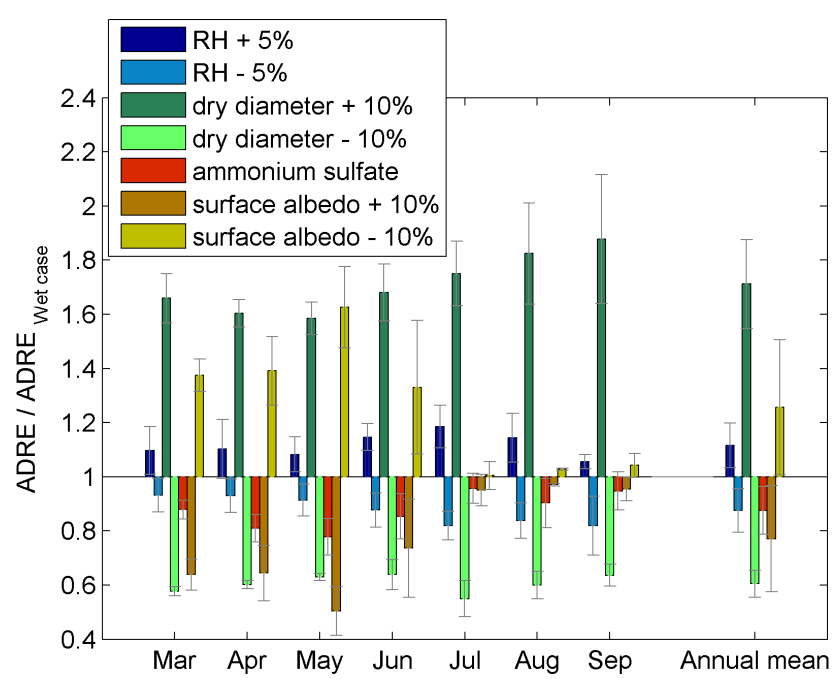

Figure 13. The sensitivity of the ratio between the calculated ADRE (new cases) and the ADRE (Wet case) to the parameters: RH, particle dry size, surface albedo and aerosol chemical composition.

albedo was varied by $\pm 10 \%$. A ratio higher than one means a higher negative ADRE, therefore more cooling at the surface, as compared with the Wet base case. The relative importance of RH and dry particle size are reversed for ADRE and surface layer scattering coefficients (see Fig. 10). For example, the effect of changing RH on the ADRE is at most $20 \%$ whereas the enhancement of $\sigma_{\text {sp }}$ was calculated to be up to $100 \%$ (most of the cases below $50 \%$ ). However, $\sigma_{\mathrm{sp}}$ changed by less than $50 \%$ when aerosol size was changed, whereas the changes in ADRE are in some cases above $80 \%$. This can be explained by the fact that the ADRE is integrated over the whole vertical column and the largest effect of RH is near the surface (see Fig. 11c), while at higher altitudes the aerosol direct forcing is governed by the concentration and dry diameter of the particles. Figure 13 also demonstrates the importance of knowing the surface albedo for accurate predictions of ADRE, particularly during the early spring months when surface albedo is higher due to the snow covered surface. Surface albedo at Ny-Ålesund changes because of snow melting and exposing the bare ground. During the transitional months, from snow cover to rock and vice versa we have high uncertainty in ADRE.

\section{Summary and conclusions}

We have investigated the seasonality and impact of hygroscopic growth on aerosol optical properties and the aerosol direct radiative effect (ADRE) in the Arctic at Ny-Ålesund, Svalbard, using a comprehensive set of observational data combined with model calculations for the year 2008. An aerosol hygroscopic growth model based on the $\kappa$-Köhler theory was utilized to calculate the aerosol particle hygroscopic growth. The optical properties and ADRE were 
investigated by coupling the hygroscopic growth model to a Mie scattering model and a radiative transfer model. Measured aerosol number size distributions, ambient RH together with aerosol chemical composition from filter samples were used as input for the model calculations. Comparisons between modeled and measured aerosol hygroscopicity and optical properties showed an agreement that gave confidence regarding the capability of the model setup to predict seasonal variations in aerosol hygroscopic growth, optical properties and ADRE.

The ambient aerosol scattering coefficients at the surface showed a clear seasonal variation with the highest values during the haze period (March-April-May) and the lowest values during summer (June-July). The hygroscopic growth of the aerosol particles was found to have a significant impact on the surface level scattering coefficients, with an annual averaged enhancement factor $f(\mathrm{RH})$ of $4.30 \pm 2.26$ at ambient RH compared to dry conditions. The impact was largest during summer and fall and smallest during the haze period in spring. The ambient RH was found to be the most important factor determining the ambient GF and $f(\mathrm{RH})$ as compared with the aerosol particle dry size and composition. In most cases, the deviation from the true value of the aerosol scattering coefficient was less than $5 \%$ when assuming a composition of pure ammonium sulfate instead of using real composition measurements. The seasonal behavior of the ADRE showed a different pattern compared to the scattering coefficients at the surface: the most negative values (i.e., the largest cooling effect) were found during July, August and September. The sensitivity of ADRE to ambient RH vs. aerosol properties was also different from the surface-level scattering coefficients with larger influence of aerosol size on the predicted ADRE. This is related to the fact that the ADRE is an integrated measure of the scattering over the whole vertical column as compared with the surface level observations of scattering coefficients. Humidity effects on particle scattering are in general largest in the boundary layer. All in all, including the hygroscopicity of the aerosol particles increased the predicted ambient ADRE with a factor of about 1.6-3.7 compared to the dry ADRE, depending on the season.

Besides the strong seasonality of aerosol optical properties and ADRE at Ny-Ålesund, our results demonstrate the importance of a correct prediction of aerosol hygroscopic growth for determining the direct aerosol effect on the Arctic radiative forcing and climate. Although the model results in this study were obtained specifically for the Zeppelin station for 2008, the developed method may be applied for other regions and time periods in future studies.

Acknowledgements. We thank the Norwegian Institute for Air Research (NILU) for providing the ion chromatography data from Zeppelin station. We also thank the Alfred Wegener Institute (AWI) for making the radio soundings and radiation data available. Financial support from the Swedish Environmental Protection Agency to conduct aerosol measurements at the Zeppelin station is acknowledged. The Nordic Centre of Excellence CRAICC (Cryosphere-Atmosphere Interactions in a Changing Arctic Climate), Vetenskapsrådet (grant 2011-5120), and the European Research Council (StG-278277 ATMOGAIN) are gratefully acknowledged. Paul Zieger was supported by a fellowship of the Swiss National Science Foundation (grant no. P300P2_147776).

Edited by: A. Massling

\section{References}

Aas, W., Solberg, S., Manø, S., and Yttri, K. E.: Overvåking av langtransportert forurenset luft og nedbør. Atmosfærisk tilførsel, 2008. Norsk institutt for luftforskning, Kjeller, OR 22/2009 (SFT (Klif) rapport nr 1051/2009), 2009.

Achtert, P., Birmili, W., Nowak, A., Wehner, B., Wiedensohler, A., Takegawa, N., Kondo, Y., Miyazaki, Y., Hu, M., and Zhu, T.: Hygroscopic growth of tropospheric particle number size distributions over the North China Plain, J. Geophys. Res, 114, D00G07, doi:10.1029/2008JD010921, 2009.

Albrecht, B. A.: Aerosols, Cloud Microphysics, and Fractional Cloudiness, Science 245, 1227-1230, 1989.

Anderson, T. L., Covert, D. S., Marshall, S. F., Laucks, M. L., Charlson, R. J., Waggoner, A. P., Ogren, J. A., Caldow, R., Holm, R. L., Quant, F. R., Sem, G. J., Wiedensohler, A., Ahlquist, N. A., and Bates, T. S.: Performance Characteristics of a High-Sensitivity, Three-Wavelength, Total Scatter/Backscatter Nephelometer, J. Atmos. Ocean. Technol., 13, 967-986, doi:10.1175/15200426(1996)013<0967:PCOAHS>2.0.CO;2, 1996.

Atwater, M. A: Planetary albedo changes due to aerosols. Science, 170, 64-66, doi:10.1126/science.170.3953.64, 1970.

Bohren, C. F. and Huffman, D. R.: Absorption and scattering of light by small particles, John Wiley \& Sons, INC, New York, 1983.

Boucher, O. and Lohmann, U.: The sulfate-CCN-cloud albedo effect, Tellus B, 47, 281-300, doi:10.1034/j.16000889.47.issue3.1.x, 1995.

Carrico, C. M., Rood, M. J., Ogren, J. A., Neususs, C., Wiedensohler, A., and Heintzenberg, J.: Aerosol optical properties at Sagres, Portugal during ACE-2, Tellus B, 52, 498-525, 2000.

Chang, H. and Charalampopoulos, T. T.: Determination of the wavelength dependence of refractive indices of flame soot, Proc. R. Soc. Lond A, 430, 577-591, 1990.

Charlson, R. J. and Pilat, M. J.: Climate: The Influence of Aerosols, J. Appl. Meteorol., 8(6), 1001-1002, doi:10.1175/15200450(1969)008<1001:CTIOA>2.0.CO;2, 1969.

Charlson, R. J., Schwartz, S. E., Hales, J. M., Cess, R. D., Coakley, J. A., Hansen, J. E., and Hofmann, D. J.: Climate Forcing by Antlropogenic Aerosols, Science 255, 423-430, 1992.

Coakley, J. A., Cess, R. D., and Yurevich, F. B.: The Effect of Tropospheric Aerosols on the Earth's Radiation Budget: A Parameterization for Climate Models, J. Atmos. Sci., 40, 116-138, doi:10.1175/1520-0469(1983)040<0116:TEOTAO>2.0.CO;2, 1983.

Covert, D. S and Heintzenberg, J.: Size distributions and chemical properties of aerosol at Ny-Ålesund, Svalbard, Atmos. Environ., 27A, 2989-2997, 1993.

Di Pierro, M., Jaeglé, L., Eloranta, E. W., and Sharma, S.: Spatial and seasonal distribution of Arctic aerosols observed by the 
CALIOP satellite instrument (2006-2012), Atmos. Chem. Phys., 13, 7075-7095, doi:10.5194/acp-13-7075-2013, 2013.

Eldering, A.: Aerosol optical properties during INDOEX based on measured aerosol particle size and composition, J. Geophys. Res., 107, 8001, doi:10.1029/2001JD001572, 2002.

Engelhart, G. J., Asa-Awuku, A., Nenes, A., and Pandis, S. N.: CCN activity and droplet growth kinetics of fresh and aged monoterpene secondary organic aerosol, Atmos. Chem. Phys., 8, 39373949, doi:10.5194/acp-8-3937-2008, 2008.

Engvall, A.-C., Ström, J., Tunved, P., Krejci, R., Schlager, H., and Minikin, A.: The radiative effect of an aged, internally mixed Arctic aerosol originating from lower-latitude biomass burning, Tellus B, 61, 677-684, doi:10.1111/j.1600-0889.2009.00431.x, 2009.

Fierz-Schmidhauser, R., Zieger, P., Gysel, M., Kammermann, L., DeCarlo, P. F., Baltensperger, U., and Weingartner, E.: Measured and predicted aerosol light scattering enhancement factors at the high alpine site Jungfraujoch, Atmos. Chem. Phys., 10, 23192333, doi:10.5194/acp-10-2319-2010, 2010a.

Fierz-Schmidhauser, R., Zieger, P., Vaishya, a., Monahan, C., Bialek, J., O’Dowd, C. D., Jennings, S. G., Baltensperger, U., and Weingartner, E.: Light scattering enhancement factors in the marine boundary layer (Mace Head, Ireland), J. Geophys. Res., 115, D20204, doi:10.1029/2009JD013755, 2010b.

Fitzgerald, J. W., Hoppel, W. A., and Vietti, M. A.: The Size and Scattering Coefficient of Urban Aerosol Particles at Washington, DC as a Function of Relative Humidity, J. Atmos. Sci., 39, 1838-1852, doi:10.1175/15200469(1982)039<1838:TSASCO>2.0.CO;2, 1982.

Hegg, D. A.: Cloud condensation nucleus-sulfate mass relationship and cloud albedo. J. Geophys. Res., 99, 25903-25907, 1994.

Hess, M., Koepke, P., and Schult, I.: Optical Properties of Aerosols and Clouds: The Software Package OPAC, Bull. Am. Meteorol. Soc., 79, 831-844, doi:10.1175/15200477(1998)079<0831:OPOAAC >2.0.CO;2, 1998.

Hjellbrekke, A. G. and Fjæraa, A. M.: Data Report 2008 Acidifying and eutrophying compounds and particulate matter, Norwegian Institute for Air Research, Kjeller, EMEP/CCC-Report 1/2010, 2010.

Intergovernmental Panel on Climate Change (IPCC), Climate Change 2013: The Scientific Basis: Contribution of Working Group I to the Fifth Assessment Report of the Intergovernmental Panel on Climate Change, Cambridge Univ. Press, New York, 2013

Jokinen, V., and Makela, J. M.: Closed-loop arrangement with critical orifice for DMA sheath excess flow system, J Aerosol Sci, 28, 643-648, 1997.

Kerker, M.: The scattering of light and other electromagnetic radiation, New York, London: Academic Press, 1969.

Kim, J., Yoon, S.-C., Jefferson, A., and Kim, S.-W.: Aerosol hygroscopic properties during Asian dust, pollution, and biomass burning episodes at Gosan, Korea in April 2001, Atmos. Environ., 40, 1550-1560, doi:10.1016/j.atmosenv.2005.10.044, 2006.

Knutson, E. O. and Whitby, K. T.: Anomalous unipolar diffusion charging of polystyrene latex aerosols, J. Colloid Interface Sci., 53, 493-495, 1975.

Koehler, K. A., Kreidenweis, S. M., DeMott, P. J., Prenni, A. J., Carrico, C. M., Ervens, B., and Feingold, G.: Water activity and activation diameters from hygroscopicity data - Part II: Ap- plication to organic species, Atmos. Chem. Phys., 6, 795-809, doi:10.5194/acp-6-795-2006, 2006.

Kotchenruther, R. A. and Hobbs, P. V.: Humidification factors of aerosols from biomass burning in Brazil, J. Geophys. Res. Atmos., 103, 32081-32089, doi:10.1029/98JD00340, 1998.

Lawrence, D. M., Slater, A. G., Tomas, R. A., Holland, M. M., and Deser, C.: Accelerated Arctic land warming and permafrost degradation during rapid sea ice loss, Geophys. Res. Lett., 35, L11506, doi:10.1029/2008GL033985, 2008.

Liu, B. Y. H., Pui, D. Y. H., Whitby, K. T., Kittelson, D. B., and Kousaka, Y.: Aerosol mobility chromatograph - new detector for sulphuric-acid aerosols, Atmos. Environ. 12, 99-104, 1978.

Liu, X., Cheng, Y., Zhang, Y., Jung, J., Sugimoto, N., Chang, S.Y., Kim, Y. J., Fan, S., and Zeng, L.: Influences of relative humidity and particle chemical composition on aerosol scattering properties during the 2006 PRD campaign, Atmos. Environ., 42, 1525-1536, doi:10.1016/j.atmosenv.2007.10.077, 2008.

McCartney, E. J.: Optics of the Atmosphere, John Wiley, New York, 1976.

McCormick, R. A. and Ludwig, J. H.: Climate Modification by Atmospheric Aerosols, Science, 156, 1358-1359, doi:10.1126/science.156.3780.1358, 1967.

McMurry, P. H. and Stolzenburg, M. R.: On the sensitivity of particle-size to relative humidity for Los-Angeles aerosols, Atmos. Environ. 23, 497-507, 1989.

Mitchell Jr., J. M.: The effect of atmospheric aerosols on climate with special reference to temperature near the Earth's surface, J. Appl. Meteorol., 10, 703-714, 1971.

Myhre, G., Stordal, F., Berglen, T. F., Sundet, J. K., and Isaksen, I. S. a.: Uncertainties in the Radiative Forcing Due to Sulfate Aerosols, J. Atmos. Sci., 61, 485-498, doi:10.1175/15200469(2004)061<0485:UITRFD>2.0.CO;2, 2004.

Nessler, R., Weingartner, E., and Baltensperger, U.: Adaptation of dry nephelometer measurements to ambient conditions at the Jungfraujoch, Environ. Sci. Technol., 39, 2219-2228, 2005.

Nilsson, E., Swietlicki, E., Sjogren, S., Löndahl, J., Nyman, M., and Svenningsson, B.: Development of an H-TDMA for longterm unattended measurement of the hygroscopic properties of atmospheric aerosol particles, Atmos. Meas. Tech., 2, 313-318, doi:10.5194/amt-2-313-2009, 2009.

Ouimette, J. R. and Flagan, R. C.: The exctinction coefficient of multicomponent aerosols, Atmos. Environ., 16, 2405-2416, 1982.

Petters, M. D. and Kreidenweis, S. M.: A single parameter representation of hygroscopic growth and cloud condensation nucleus activity, Atmos. Chem. Phys., 7, 1961-1971, doi:10.5194/acp-71961-2007, 2007.

Pilinis, C., Pandis, S. N., and Seinfeld, J. H.: Sensitivity of direct climate forcing by atmospheric aerosols to aerosol size and composition, J. Geophys. Res., 100, 18739, doi:10.1029/95JD02119, 1995.

Quinn, P. K., Miller, T. L., Bates, T. S., Ogren, J. A., Andrews, E., and Shaw, G. E.: A 3- year record of simultaneously measured aerosol chemical and optical properties at Barrow, Alaska, J. Geophys. Res. Atmos., 107, 4130, doi:10.1029/2001JD001248, 2002.

Quinn, P. K., Shaw, G., Andrews, E., Dutton, E. G., RuohoAirola, T., and Gong, S. L.: Arctic haze: current trends and 
knowledge gaps, Tellus B, 59, 99-114, doi:10.1111/j.16000889.2006.00238.x, 2007.

Radke, F. S., Lyons, J. H., Hegg, D. A., Hobbs, P. V. and Bailey, I. H.: Airborne observations of Arctic aerosols, I, Characteristics of Arctic haze. Geophys. Res. Lett., 11, 393-396, 1984.

Ricchiazzi, P., Yang, S., Gautier, C., and Sowle, D.: SBDART: a research and teaching software tool for plane-parallel radiative transfer in the Earth's atmosphere, B. Am. Meteorol. Soc., 79, 2101-2114, 1998.

Schkolnik, G., Chand, D., Hoffer, A., Andreae, M.O., Erlick, C., Swietlicki, E., and Rudich, Y.: Constraining the density and complex refractive index of elemental and organic carbon in biomass burning aerosol using optical and chemical measurements, Atmos. Environ., 41, 1107-1118, 2007.

Seinfeld, J. H. and Pandis, S. N.: Atmospheric Chemistry and Physics, Wiley, NewYork, 1998.

Sekigawa, K.: Estimation of the volume fraction of water soluble material in submicron aerosols in the atmosphere, J. Meteorol. Soc. Japan, 61, 359-367, 1983.

Serreze, M. C. and Barry, R. G.: Processes and impacts of Arctic amplification: A research synthesis, Glob. Planet. Change, 77, 85-96, doi:10.1016/j.gloplacha.2011.03.004, 2011.

Serreze, M. C., Holland, M. M., and Stroeve, J.: Perspectives on the Arctic's shrinking sea-ice cover, Science, 315, 1533-1536, doi:10.1126/science.1139426, 2007.

Sheridan, P. J., Delene, D. J., and Ogren, J. A.: Four years of continuous surface aerosol measurements from the Department of Energy's Atmospheric Radiation Measurement Program Southern Great Plains Cloud and Radiation Testbed site, J. Geophys. Res., 106, 20735-20747, 2001.

Shindell, D. and Faluvegi, G.: Climate response to regional radiative forcing during the twentieth century. Nat. Geosci., 2, 294-300, 2009.

Silvergren, S., Wideqvist, U., Ström, J., Sjogren, S, and Svenningsson, B.: Hygroscopic growth and cloud forming potential of Arctic aerosol based on observed chemical and physical characteristics (a 1 year study 2007-2008), J. Geophys. Res. Atmos, in review, 2014.

Ström, J., Umegård, J., Tørseth, K., Tunved, P., Hansson, H.-C., Holmén, K., Wismann, V., Herber, A., and König-Langlo, G.: One year of particle size distribution and aerosol chemical composition measurements at the Zeppelin Station, Svalbard, March 2000-March 2001, Phys. Chem. Earth, Parts A/B/C, 28, 11811190, doi:10.1016/j.pce.2003.08.058, 2003.

Svenningsson, B., Rissler, J., Swietlicki, E., Mircea, M., Bilde, M., Facchini, M. C., Decesari, S., Fuzzi, S., Zhou, J., Mønster, J., and Rosenørn, T.: Hygroscopic growth and critical supersaturations for mixed aerosol particles of inorganic and organic compounds of atmospheric relevance, Atmos. Chem. Phys., 6, 1937-1952, doi:10.5194/acp-6-1937-2006, 2006.

Swietlicki, E., Hansson, H.-C., Hämeri, K., Svenningsson, B., Massling, A., Mcfiggans, G., Mcmurry, P. H., Petäjä, T., Tunved, P., Gysel, M., Topping, D., Weingartner, E., Baltensperger, U., Rissler, J., Wiedensohler, A., and Kulmala, M.: Hygroscopic properties of submicrometer atmospheric aerosol particles measured with H-TDMA instruments in various environments - a review, Tellus B, 60, 432-469, 2008.
Treffeisen, R., Krejci, R., Ström, J., Engvall, A. C., Herber, A., and Thomason, L.: Humidity observations in the Arctic troposphere over Ny-Ålesund, Svalbard based on 15 years of radiosonde data, Atmos. Chem. Phys., 7, 2721-2732, doi:10.5194/acp-7-27212007, 2007.

Tunved, P., Ström, J., and Krejci, R.: Arctic aerosol life cycle: linking aerosol size distributions observed between 2000 and 2010 with air mass transport and precipitation at Zeppelin station, Ny-Ålesund, Svalbard, Atmos. Chem. Phys., 13, 3643-3660, doi:10.5194/acp-13-3643-2013, 2013.

Twomey, S.: The Influence of Pollution on the Shortwave Albedo of Clouds, J. Atmos. Sci., 34 1149-1152, doi:10.1175/15200469(1977)034<1149:TIOPOT>2.0.CO;2, 1977.

Van de Hulst, H. C.: Light Scattering By Small Particles, John Wiley \& Sons, Inc., New York, 1957.

Wallén, A., Lidén, G., and Hansson, H.-C.: Measured elemental carbon by thermo-optical transmittance analysis in water-soluble extracts from diesel exhaust, woodsmoke, and ambient particulate samples. J. Occup. Environ. Hyg., 7, 35-45, 2010.

Winker, D. M., Tackett, J. L., Getzewich, B. J., Liu, Z., Vaughan, M. A., and Rogers, R. R.: The global 3-D distribution of tropospheric aerosols as characterized by CALIOP, Atmos. Chem. Phys., 13, 3345-3361, doi:10.5194/acp-13-3345-2013, 2013.

Wiscombe, W.: Mie scattering calculations: Advances in technique and fast, vector-speed computer codes, NCAR Tech. Note TN140+STR, Natl. Cent. for Atmos. Res., Boulder, Colorado, 1979.

Yu, H., Kaufman, Y. J., Chin, M., Feingold, G., Remer, L. A., Anderson, T. L., Balkanski, Y., Bellouin, N., Boucher, O., Christopher, S., DeCola, P., Kahn, R., Koch, D., Loeb, N., Reddy, M. S., Schulz, M., Takemura, T., and Zhou, M.: A review of measurement-based assessments of the aerosol direct radiative effect and forcing, Atmos. Chem. Phys., 6, 613-666, doi:10.5194/acp-6-613-2006, 2006.

Zieger, P., Fierz-Schmidhauser, R., Gysel, M., Ström, J., Henne, S., Yttri, K. E., Baltensperger, U., and Weingartner, E.: Effects of relative humidity on aerosol light scattering in the Arctic, Atmos. Chem. Phys., 10, 3875-3890, doi:10.5194/acp-10-38752010, 2010.

Zieger, P., Weingartner, E., Henzing, J., Moerman, M., de Leeuw, G., Mikkilä, J., Ehn, M., Petäjä, T., Clémer, K., van Roozendael, M., Yilmaz, S., Frieß, U., Irie, H., Wagner, T., Shaiganfar, R., Beirle, S., Apituley, A., Wilson, K., and Baltensperger, U.: Comparison of ambient aerosol extinction coefficients obtained from in-situ, MAX-DOAS and LIDAR measurements at Cabauw, Atmos. Chem. Phys., 11, 2603-2624, doi:10.5194/acp11-2603-2011, 2011.

Zieger, P., Fierz-Schmidhauser, R., Weingartner, E., and Baltensperger, U.: Effects of relative humidity on aerosol light scattering: results from different European sites, Atmos. Chem. Phys., 13, 10609-10631, doi:10.5194/acp-13-10609-2013, 2013.

Zieger, P., Fierz-Schmidhauser, R., Poulain, L., Müller, T., Birmili, W., Spindler, G., Wiedensohler, A., Baltensperger, U., and Weingartner, E.: Influence of water uptake on the aerosol particle light scattering coefficients of the Central European aerosol, Tellus B, 66, 1-14, 2014. 